\title{
MORTALITY FROM CARDIOVASCULAR DISEASES
}

AND LIFE EXPECTANCY IN RUSSIA *

\author{
ANATOLY VISHNEVSKY, EVGENY ANDREEV, SERGEY TIMONIN
}

\begin{abstract}
High premature mortality from cardiovascular disease (CVD) and its long-term negative trends are one of the main reasons for Russia's lag behind the developed countries in life expectancy, especially of its female population. Despite the decline in mortality since 2003, CVD mortality rates at particular ages (30-74 years for males and 30-49 for females) are still higher than in 1970.
\end{abstract}

Decomposition of long-term changes in life expectancy in Russia shows a negative contribution of changes in CVD mortality for men (-1.0 years in 1972-2010) and a small positive contribution for women ( +0.7 years from 1972 to 2010).

The mortality structure within the full class of cardiovascular diseases in Russia is significantly different from that observed in the countries with the lowest level of CVD mortality. Ischemic heart disease constitutes more than half of all deaths, and this share, in contrast to Western countries, is tending to rise. Second place belongs to deaths from cerebrovascular diseases, the share of which is declining, but remains significantly higher than in Western countries. The share of deaths from other cardiovascular diseases accounts for about $50 \%$ of all CVD mortality in Western countries, while in Russia it is only about 15\%, but these are characterized by a very low age at death.

Regional patterns of CVD mortality in Russia are discussed, as well as the quality of statistics on causes of death and changes in the coding practices in the Russian Federation.

Key words: mortality, life expectancy, cardiovascular diseases, ischemic heart disease, cerebrovascular diseases, age-specific mortality pattern, average age at death, excess mortality.

The demographic development of the Russian Federation is determined by the interaction of the three main demographic processes: fertility, mortality and migration. Each of these processes in modern Russia takes place in a mode far from optimal, generating many problems of concern to society and seen as challenges requiring answers.

One such challenge, perhaps the most acute, is associated with the very high mortality rate and, accordingly, low life expectancy for Russians.

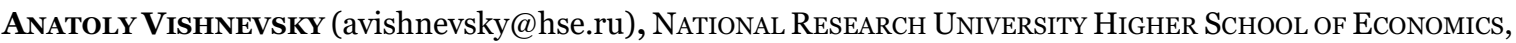
RUSSIA.

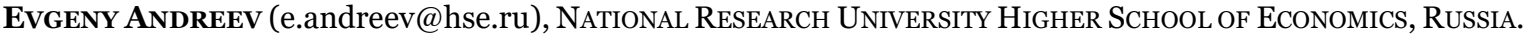
SERGEY Timonin (stimonin@hse.ru), NATIONAL RESEARCH University Higher SCHOOl of Economics, Russia.
}

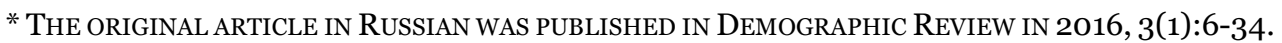
DOI: //DOI.ORG/10.17323/DEMREVIEW.V3I1.1761.

THE RESULTS OF THE PROJECT “DEMOGRAPHIC DEVELOPMENT IN RUSSIA IN 2005-2015 IN THE CONTEXT OF LONG-TERM TRENDS”, CARRIED OUT WITHIN THE FRAMEWORK OF THE BASIC RESEARCH PROGRAMME AT THE NATIONAL RESEARCH UNIVERSITY HIGHER SCHOOL OF ECONOMICS (HSE) IN 2016, ARE PRESENTED IN THIS PAPER. 


\section{RUSSIA'S LIFE EXPECTANCY LAG}

By the mid-1960s, most developed industrial countries had managed to rein in the main source of high mortality in the past - infectious diseases. Thanks to this, life expectancy in much of the developed world between the beginning of the twentieth century and 1960 increased by 20 years or more, and Russia, which had a very low initial level, was among the countries showing the greatest gains: 34 more years for men, and 40 more for women (Figure 1).

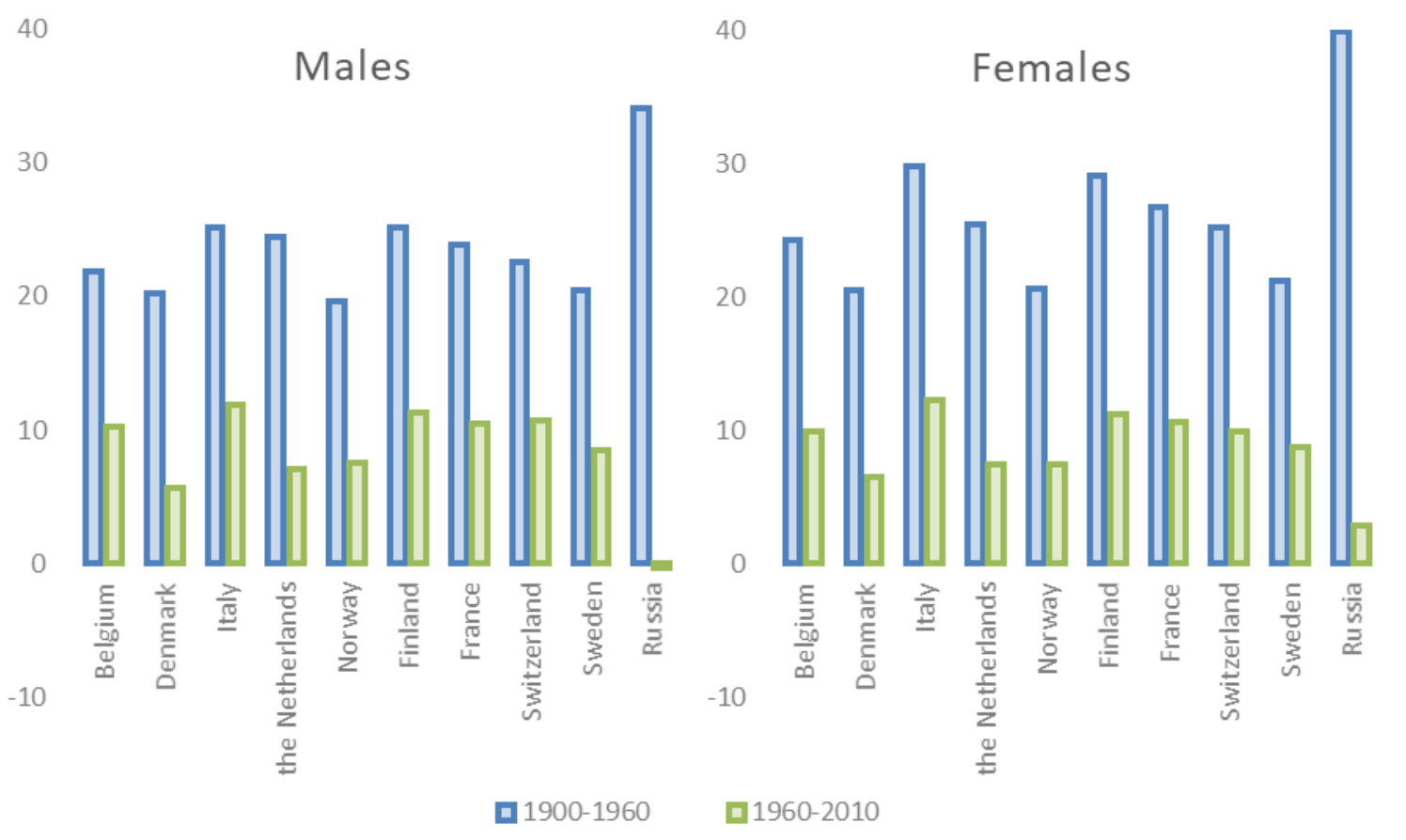

Figure 1. Growth of life expectancy in some countries during the first and second epidemiological revolutions, years

Source: Authors' calculations according to [RosBRiS 2015; HLD 2015; HMD 2015].

This was a real revolution, as a result of which life expectancy in many developed countries increased on average to 70 years, its further growth slowed significantly, and the main causes of death became "degenerative diseases and diseases associated with human activities" [Omran 2005: 738]. Assessing the current situation, experts have concluded that the possibilities of the previous strategy to increase life expectancy, focused primarily on the prevention and treatment of infectious diseases, are being exhausted, and that this strategy needs to be rethought. As American hygienist Milton Terris wrote, it became necessary to carry out a "second epidemiological revolution" [Terris 1976: 1159].

The world has really entered a new era - the era of combating non-communicable causes of death (chronic diseases, as well as accidents and injuries). Approximately from the late 1960s to the early 1970s, in most developed countries there was a process of active transformation of the epidemiological model of mortality that had developed by that time as a result of the successes achieved in the previous stage in the fight against infectious diseases. And it was the late 1960s and early 1970s that became the point at which the paths towards reducing mortality in industrial countries began to diverge - the transition to a new model of mortality was not underway everywhere. 
It was successful in countries of Western Europe, North America, Japan and some other countries, where there has been a persistent tendency to increased life expectancy (of about 2.5 years a decade). In the countries of Central and Eastern Europe, however, no improvements occurred. In the USSR, this unfortunate situation was hushed up for a long time, and it was only in the late 1980s that it became possible to say publicly that the country, "beginning roughly in the mid-sixties, entered a long period of 'going nowhere'. Also persisting, and in some cases even growing, was the already relatively high mortality, especially among working-age men; the USSR's lag behind most of the world's economically developed countries in terms of mortality rates and length of life increased "[Vishnevsky 1986: 71-72].

All this applied to Russia, too. The winning changes that took place during the first epidemiological revolution turned out to be losing ones at a later stage, when the second epidemiological revolution unfolded in the world. For 50 years (between 1960 and 2010) the life expectancy of women grew only slightly - much less than in most developed countries - while for men it even decreased somewhat (Figure 1).

The negative trends in Central Europe were brought to a halt in the late 1980s, and in the Baltics in the mid-1990s. In Russia, the changes that have taken place since the late 1980s, when the highest life expectancy indicators were reached, have been of an oscillatory nature. At first, the indicators fell sharply, reaching the bottom in 1994, after which they returned to their previous level. The fall took 4-6 years, while the process of restoring the level of the late 1980s, temporarily interrupted in 1998, took a total of 15 years for women and 19 years for men. At the same time, the lag behind the majority of developed countries grew substantially. If we take for comparison the 15 Western European countries ${ }^{1}$ that were part of the European Union before its expansion in 2004 (EU-15), then in 1988 life expectancy for men in Russia was 8 years lower than in these countries, and 5 years lower for women. 25 years later, in 2013, after a number of fluctuations, the gap was 13.9 years for men and 7.9 years for women. If we compare with each of the most successful countries (France, Italy, Spain, Japan), the gap will be even greater. The growing gap between Russia and the countries that have overtaken it in life expectancy, including the former "socialist camp", is clearly seen in Figure 2.

The observed lag is largely determined by two distinctive features of the contemporary Russian model of mortality: very high mortality from diseases of the circulatory system among the middle-aged, and very high mortality from external causes among the young and middle-aged [Vishnevsky, Shkolnikov 1997: 24]. This article examines one of these two features in more detail: the high mortality of Russians from diseases of the circulatory system.

\footnotetext{
${ }^{1}$ Austria, Belgium, Great Britain, Germany, Greece, Denmark, Italy, Ireland, Spain, Luxembourg, the Netherlands, Portugal, Finland, France, Sweden.
} 


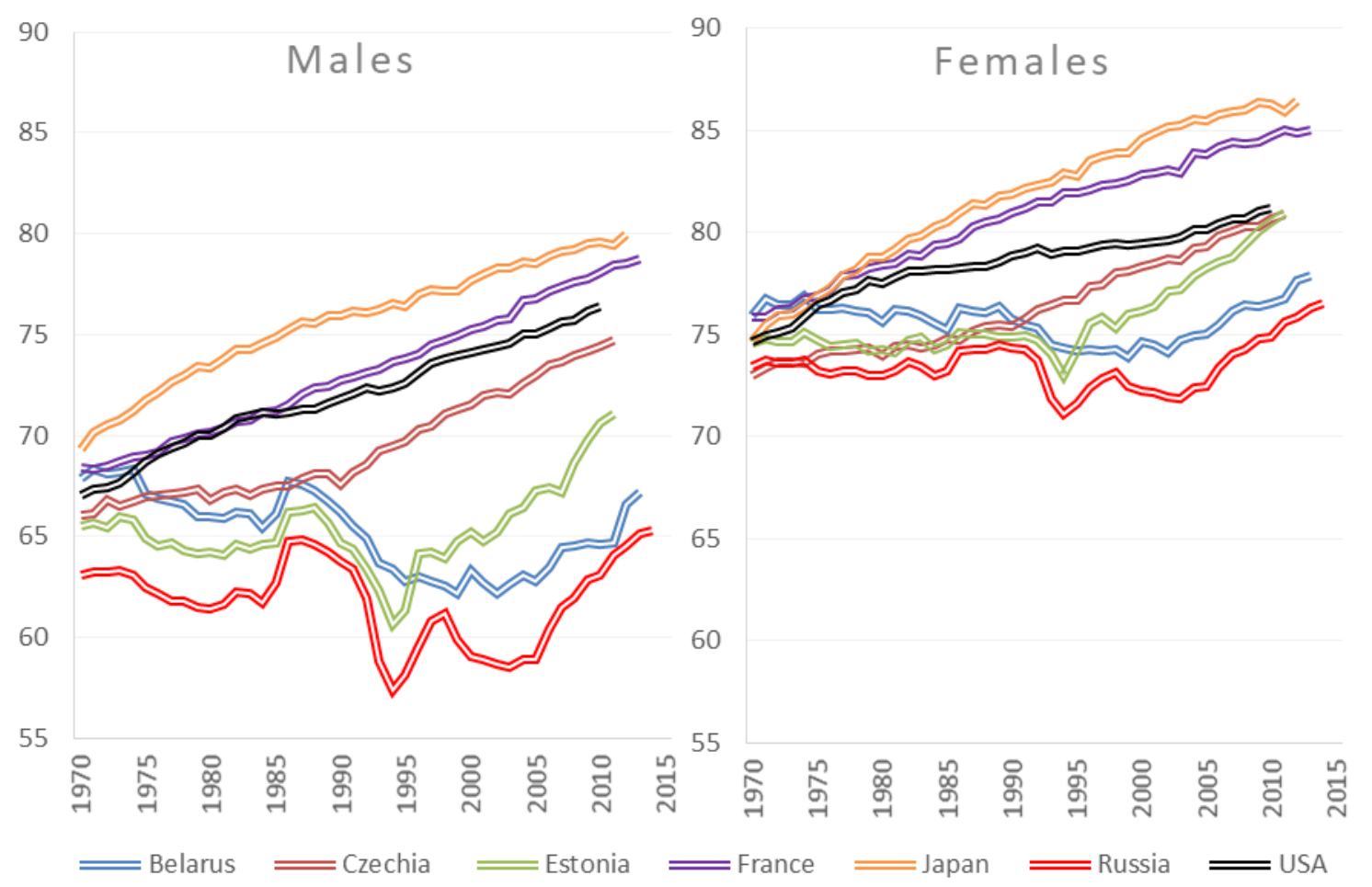

Figure 2. Life expectancy at birth in Russia and several countries of the world, years

Source: Authors' calculations according to [RosBRiS 2015; HLD 2015; HMD 2015].

\section{ADVERSE TRENDS IN MORTALITY FROM CARDIOVASCULAR DISEASES IN RUSSIA}

In historical retrospect, high mortality from cardiovascular diseases is not a problem, but a boon. In the second half of the $19^{\text {th }}$ and the first half of the $20^{\text {th }}$ centuries, the rapid growth of mortality from causes of mainly endogenous etiology, primarily circulatory diseases and neoplasms, was a highly progressive process. It is due to the fact that the increase in the probability of dying from these causes simultaneously meant a decrease in the probability of dying from exogenous causes, above all from infectious diseases, which was the same thing as a displacement of deaths in childhood and young age by deaths of people in elderly and old age and hence a rapid growth of life expectancy.

As a result of these changes, mortality from cardiovascular diseases has become the most important, the dominant part of overall mortality in all developed countries, and for Russia this is even more characteristic than for Western countries. Over the last decades of the last century, the probability of dying from causes of this class changed somewhat, but its determining role persisted: about half of men and $65-70 \%$ of women died from this cause, which already even then made the Russian mortality model significantly different from the western one, where the probability of dying from diseases of the circulatory system was significantly lower [Vishnevsky, Shkolnikov 1997: 27]. 
The increase in the contribution of CVD to total mortality (at that time, a positive phenomenon) was combined with an increase in the average age at death from this cause, including in the USSR, where "for a long time mortality from CVD... decreased in younger age groups - its growth was observed only among those over 50, and even here it could be associated with the improvement of diagnostics" [Vosproizvodstvo naseleniya SSSR 1983: 111]. However, already in the second half of the 1960s "a new trend was revealed - towards an increase in mortality in middle age, in which it had previously declined" [Vosproizvodstvo naseleniya SSSR 1983: 112]. As a result, "the average age at deaths from cardiovascular diseases from 1966-1967 to 1971-1972 decreased in women by about one year, and for men even by two" [Biryukov 1979: 66].

The "alarming trends" of mortality from cardiovascular diseases in Russia were also pointed out in later works. For example, a comparison of Russia with France in the mid-1990s showed that in Russia "mortality from cardiovascular diseases is significantly higher than in France, and, most importantly, has been increasing over the past 30 years, while in France there has been a continuous reduction ... This fundamental difference indicates that Russia, unlike Western countries, has not yet embarked on an effective way to combat cardiovascular diseases, which would allow it to enter a new phase of the epidemiological transition" [Meslé et al. 1996: 117-118].

Apparently, this new phase has not yet begun in Russia even now, although, for the sake of truth, it must be said that this concerns not only cardiovascular diseases. By the early 1970s, in Russia, as in all developed countries, infectious diseases had lost their recent role as a major threat to human health and life, and non-infectious causes of morbidity, disability and mortality, primarily three of their main classes, had come to the fore: cardiovascular diseases, neoplasms and the so-called external causes of death caused not by disease, but by intentional or accidental external effects.

In 1970, the cumulative share of these three groups of causes in the standardized death rate (SDR) from all causes in Western Europe was close to $70 \%$ and in subsequent years even increased, while in Russia it had already reached $80 \%$. Accordingly, the tasks of combating mortality were reduced and still are primarily reduced to a reduction in mortality from the three specified groups of causes [Vishnevsky, 2014]. 


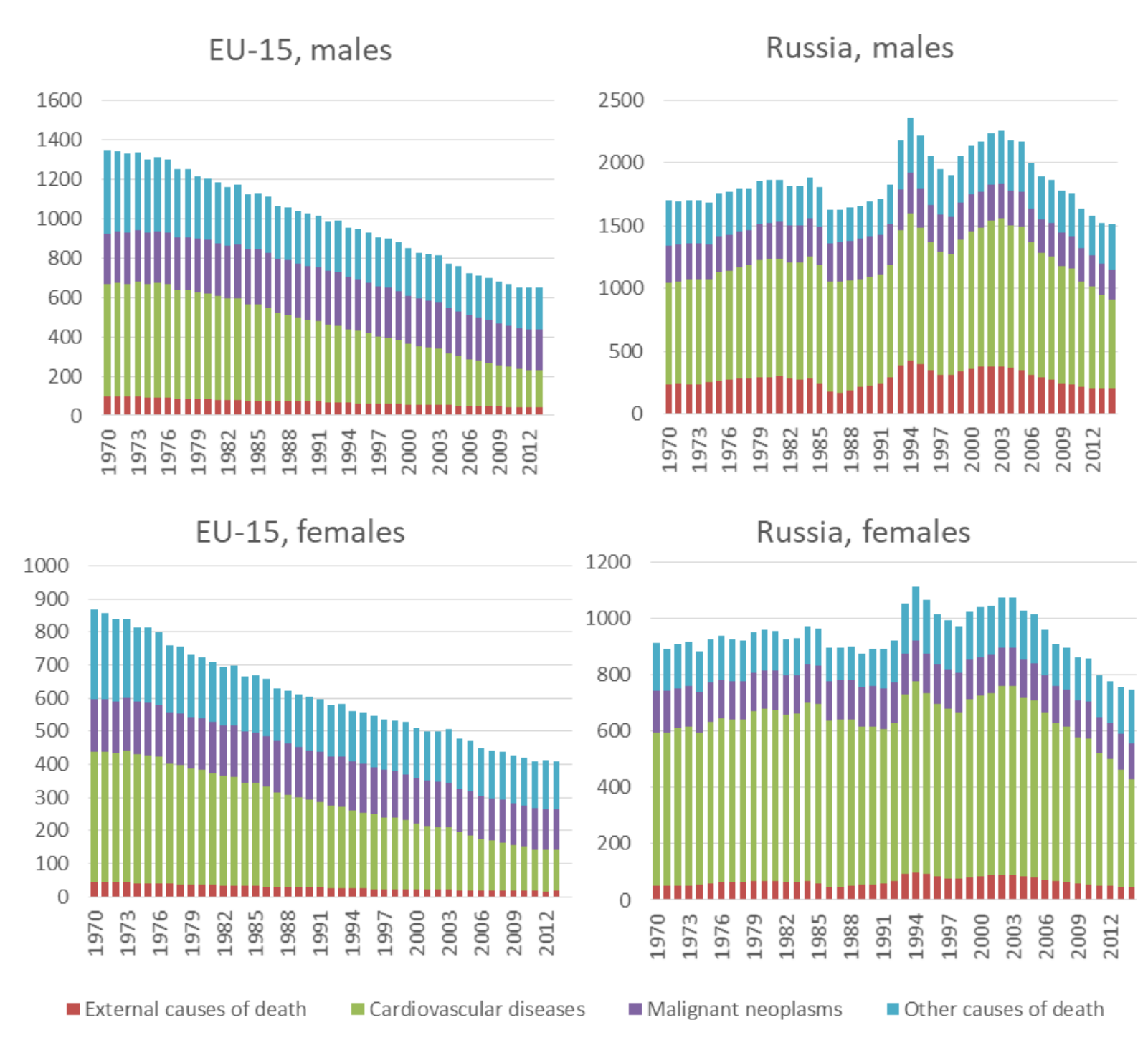

\section{Figure 3. The standardized death rate from CVD, malignant neoplasms, external causes and other causes of death in the EU-15 and Russia, per 100000}

Source: Authors' calculations according to [RosBRiS 2015; WHO MD 2015]

Judging by the dynamics of the standardized death rate after 1970, these tasks were successfully solved in western European countries (Figure 3, left panel). At the same time, the graph clearly shows that the whole picture of changes over the last few decades has been determined by the decrease in the standardized death rate from CVD, which led to a general decrease in the standardized death rate in these countries. The standardized death rate from the other two main classes of non-communicable causes has changed insignificantly (although in the case of external causes, its decrease is still noticeable). It is no accident that in the modern demographic literature the changes in mortality that occurred in the last half century have been called "a cardiovascular revolution" [Meslé, Vallin 2006: 250].

In Russia, events developed in a different way. As can be seen from the same figure 3 (right panel) and from Table 1, it is not yet possible to speak of a serious reduction in mortality from CVD - since 1970 it has barely changed. It is barely possible to speak of a serious change in the aggregate standardized death rate from the three classes of causes, given that over the last half- 
century it has undergone essentially oscillatory changes, only in the second half of the aughts showing a more or less pronounced tendency to fall below the levels previously reached.

Table 1. The standardized death rate from some classes of causes of death in Russia, 1970-2014, per 100000

\begin{tabular}{|c|c|c|c|c|c|c|}
\hline & 1970 & 1980 & 1990 & 2000 & 2010 & 2014 \\
\hline & \multicolumn{6}{|c|}{ Men } \\
\hline All causes & 1704.5 & 1868.2 & 1695.4 & 2143.6 & 1756.5 & 1513.2 \\
\hline \multicolumn{7}{|l|}{ Including: } \\
\hline - Cardiovascular diseases & 809.0 & 946.2 & 868.0 & 1091.8 & 920.5 & 702.1 \\
\hline - Malignant neoplasms & 287.2 & 284.5 & 318.6 & 294.4 & 262.8 & 241.0 \\
\hline - External causes & 238.8 & 292.1 & 228.7 & 360.5 & 237.3 & 204.4 \\
\hline Total for the 3 classes of causes & 1335.0 & 1522.8 & 1415.3 & 1746.7 & 1420.6 & 1147.5 \\
\hline - Other causes & 369.5 & 345.4 & 280.1 & 396.9 & 335.9 & 365.8 \\
\hline & \multicolumn{6}{|c|}{ Women } \\
\hline $\begin{array}{l}\text { All causes } \\
\text { including: }\end{array}$ & 911.7 & 959.1 & 893.3 & 1039.2 & 858.9 & 747.2 \\
\hline - Cardiovascular diseases & 544.9 & 610.4 & 561.9 & 641.4 & 517.6 & 382.4 \\
\hline - Malignant neoplasms & 146.2 & 135.8 & 142.8 & 139.8 & 131.8 & 123.1 \\
\hline - External causes & 51.1 & 68.0 & 55.8 & 83.3 & 56.9 & 47.8 \\
\hline Total for the 3 classes of causes & 742.2 & 814.2 & 760.5 & 864.5 & 706.3 & 553.4 \\
\hline - Other causes & 169.5 & 144.9 & 132.8 & 174.7 & 152.6 & 193.8 \\
\hline
\end{tabular}

Source: Authors' calculations according to [RosBRiS 2015; WHO MD 2015]

\section{HIGH MORTALITY FROM CARDIOVASCULAR DISEASES IS THE MAIN CAUSE OF LOW LIFE EXPECTANCY IN RUSSIA}

High mortality from cardiovascular diseases is the main culprit in Russia's lag behind other countries in terms of life expectancy. It accounts for $45-55 \%$ of this gap in men and even more in women (Table 2).

Table 2. The contribution of differences in mortality from CVD in Russia's overall life expectancy lag behind some countries

\begin{tabular}{|c|c|c|c|c|c|c|}
\hline \multirow{3}{*}{ Country, year } & \multicolumn{3}{|c|}{ Men } & \multicolumn{3}{|c|}{ Women } \\
\hline & \multirow[t]{2}{*}{$\begin{array}{l}\text { Differences in life } \\
\text { expectancy, years }\end{array}$} & \multicolumn{2}{|c|}{$\begin{array}{l}\text { Including due to } \\
\text { higher mortality } \\
\text { from CVD }\end{array}$} & \multirow[t]{2}{*}{$\begin{array}{l}\text { Differences in life } \\
\text { expectancy, years }\end{array}$} & \multicolumn{2}{|c|}{$\begin{array}{c}\text { Including due to } \\
\text { higher mortality from } \\
\text { CVD }\end{array}$} \\
\hline & & years & $\%$ & & years & $\%$ \\
\hline Japan, 2013 & 15.4 & 7.9 & 51.1 & 11.0 & 7.9 & 71.3 \\
\hline France, 2011 & 13.5 & 7.6 & 55.8 & 9.2 & 7.3 & 78.8 \\
\hline Germany, 2012 & 13.4 & 6.4 & 47.6 & 7.0 & 4.8 & 69.0 \\
\hline USA, 2010 & 11.4 & 6.1 & 53.4 & 5.0 & 5.0 & 98.1 \\
\hline Estonia, 2012 & 10.1 & 4.3 & 42.7 & 4.9 & 2.9 & 60.3 \\
\hline Czechia, 2013 & 6.2 & 2.8 & 44.3 & 5.1 & 2.7 & 53.7 \\
\hline
\end{tabular}

Note: The data for Russia used for comparison is for 2013 (life expectancy was 65.1 and 76.4 years for men and women, respectively).

Source: Authors' calculations according to [RosBRiS 2015; WHO MD 2015].

Since the early 1970s, the mortality rate in Russia has experienced several periods of recovery and recession, each of which was closely related to the ups and downs of mortality from diseases of the circulatory system (Figures 4 and 5). 
Because the periods of growth and decrease in mortality from CVD alternated, it is possible to find periods when the fight against this cause of death can be considered successful. In particular, this interpretation can be proposed for the period from 2004, when, as follows from Figures 4 and 5, the contribution of diminishing mortality from cardiovascular diseases to the growth of life expectancy was greater than in many other countries [Grigoriev et al. 2014]. However, one must take into account that, basically, this contribution was compensated by the losses incurred in previous periods. From the long-term perspective (for the period from 1972, which is reflected in Figures 4 and 5), the total contribution of changes in mortality from CVD to changes in life expectancy in women was positive, but very small compared to other countries, and in men was completely negative.

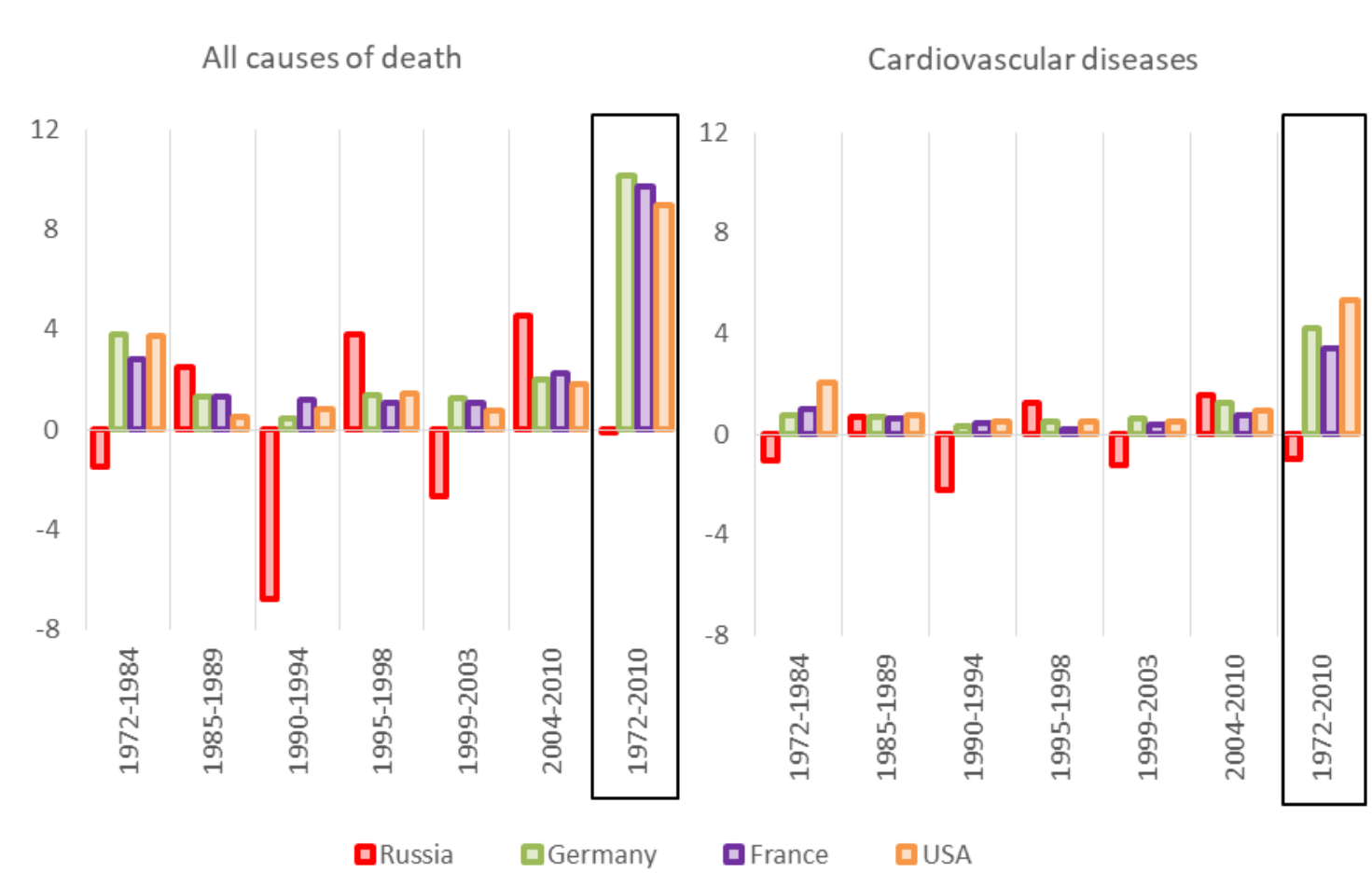

Figure 4. Changes in life expectancy at birth as a result of an increase or decrease in mortality from all causes and diseases of the circulatory system in Russia, Germany, France and the US, men, years

Source: Authors' calculations according to [RosBRiS 2015; WHO MD 2015]. 


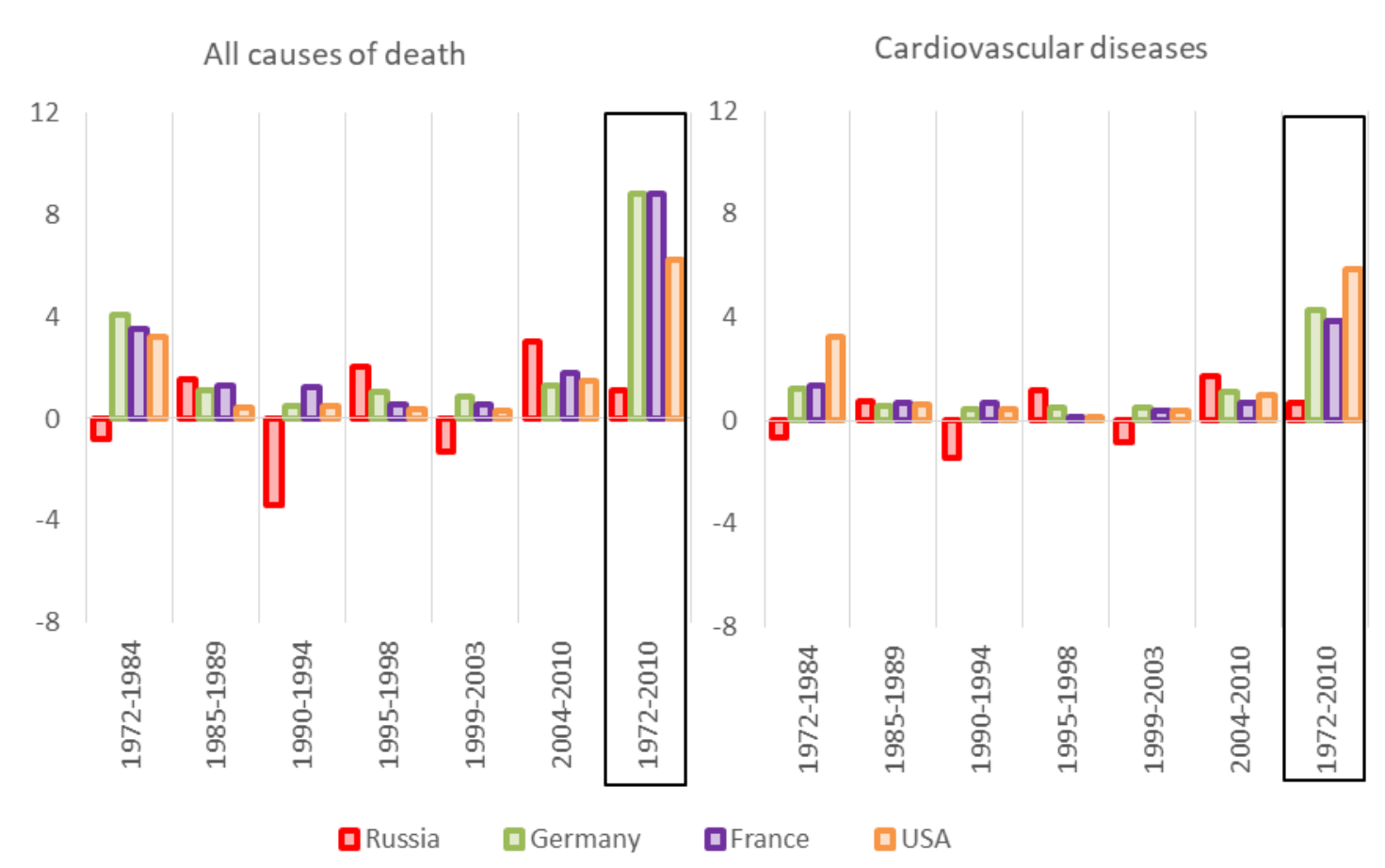

Figure 5. Changes in life expectancy at birth as a result of an increase or decrease in mortality from all causes and diseases of the circulatory system in Russia, Germany, France and the United States, women, years

Source: Authors' calculations according to [RosBRiS 2015; WHO MD 2015].

\section{THE STRUCTURE OF CARDIOVASCULAR MORTALITY IN RUSSIA}

The whole class of cardiovascular diseases can be broken down into three main groups: ischemic heart disease (ICD-10 codes [WHO 1995] - I20-I25), cerebrovascular diseases (codes I60-I69) and all other causes of this class (other heart diseases - codes I00-I19, I26-I59 and other cardiovascular diseases - codes I70-199). Comparison of the structure of mortality from these three groups of causes in Russia and in countries with lower and decreasing mortality from CVD suggests that here, too, Russia is following its own - and not the best - path.

In the 1970s, attempts were made to link the unfavorable trends in mortality from CVD in Russia with the different roles of exogenous and endogenous causes and conditions for the emergence of different groups of cardiovascular diseases. It was supposed that "such diseases as active rheumatism and chronic rheumatic heart disease can be considered mainly as diseases of exogenous etiology, whereas coronary heart disease and cerebral vascular lesions are mainly endogenous diseases" (Biryukov 1979: 69). The logic of this contrast was that the greater role of the exogenous component in determining certain cardiovascular diseases makes them less dependent on age and at the same time more sensitive to those methods of combating diseases and death that brought success in the earlier stages of the epidemiological transition. The gaining of control over age-related exogenous factors of cardiovascular morbidity in a sense could be considered as an extension of this success, increasing the chances of reducing mortality from those diseases of the circulatory system in whose etiology the role of this factor was highest. 
Given that the main contribution to cardiovascular mortality is caused by ischemic heart disease and cerebral vascular lesions, Biryukov believed that it would be interesting to link the differences in the dynamics of mortality from these two groups of the disease with the different contributions of exogenous and endogenous components to their etiology. However, he was unable to do this, and had to admit that "for now it is not possible to make such an analysis convincing" [Biryukov 1979: 74]. Noting, though, that both coronary heart disease and cerebral vascular lesions are based either on atherosclerosis or hypertension, with atherosclerosis being the main cause of the first and hypertension of the second, V. Biryukov draws attention to the fact that "the fight against hypertension is being waged more successfully", and makes the cautious assumption that "mortality from hypertension is less closely related to age, and therefore to a lesser extent serves as an inevitable companion to the aging process"[Biryukov 1979: 75]. In other words, it is less dependent on environmental and behavioral factors.

Apparently, this assumption, like the whole logic of Biryukov's reasoning, was not without grounds. Already in the 90s, the authors of the aforementioned comparative mortality study in Russia and France came to the conclusion that, in Russia, "favorable trends of change are observed for certain heart diseases, such as rheumatic heart diseases and hypertension. Reducing mortality from the first of these pathologies, which is of an infectious nature, may be associated with the spread of antibiotics" [Meslé et al. 1996: 119]. "Progress in fighting hypertension is also significant, although the decline in mortality from it, especially intense in the 1970s, later slowed. In the 1980s, the death rate from hypertension in Russia decreased to the level of France" (however, here it was stated that "this evolution of mortality from hypertension in Russia is more associated with a change in the practice of coding the causes of death than with real changes") [Meslé et al. 1996: 119].

If, with regard to heart diseases, even while noting Russia's great lag behind France, the authors of the study pointed to some trends opposing the increase in mortality, then "the second major component of mortality from cardiovascular disease - strokes - has continuously grown over the past 30 years, which is in sharp contrast to the marked decrease in mortality from this pathology in France "[Meslé et al. 1996: 119].

In light of this reasoning, the growth in Russia during the second half of the 1990s of the previously decreased contribution of ischemic heart disease to overall CVD mortality seems surprising. Now it determines more than half of the standardized death rate from diseases of the circulatory system in men and not much less in women, and there is no sign yet of this trend slowing down. In Western European countries, this contribution is much smaller, and in the last two decades has tended to decrease (Figure 6). Is this not connected with the prolonged inability of Russian society to limit the effect of external factors that are less dependent on age?

Among these factors is, in particular, alcohol. Numerous studies emphasize the connection between excessive consumption of alcohol and premature mortality from diseases of the circulatory system, but the exact mechanism of this connection remains unclear. Sometimes it is even suggested that this relationship is only an appearance that arises from the fact that some of the deaths due to alcohol poisoning are classified as consequences of heart disease [Zaridze et al. 2009]. At the same time, Leon et al. [Leon et al. 2010], according to a retrospective study of the mortality of men in Izhevsk in 2003-2005, found a stable statistical relationship between excessive 
alcohol consumption and mortality from forms of coronary heart disease, except for myocardial infarction (ICD codes I20, I23-I25). It is also noted that the reduction of mortality from diseases of the circulatory system during the anti-alcohol campaign was associated with these forms of ischemic disease.

In Western countries, the contribution to cardiovascular mortality of cerebrovascular diseases is rapidly declining, while in Russia this decline has only recently appeared, and so far this contribution remains high: among women it is approximately the same as in France in 1980, and among men is not much less (Figure 7).

Accordingly, in Russia the contribution of all other cardiovascular diseases, which is constantly growing in other countries, is very low. True, since 2000 it has been growing in Russia, but the gap behind western European countries is still very large (Figure 8).

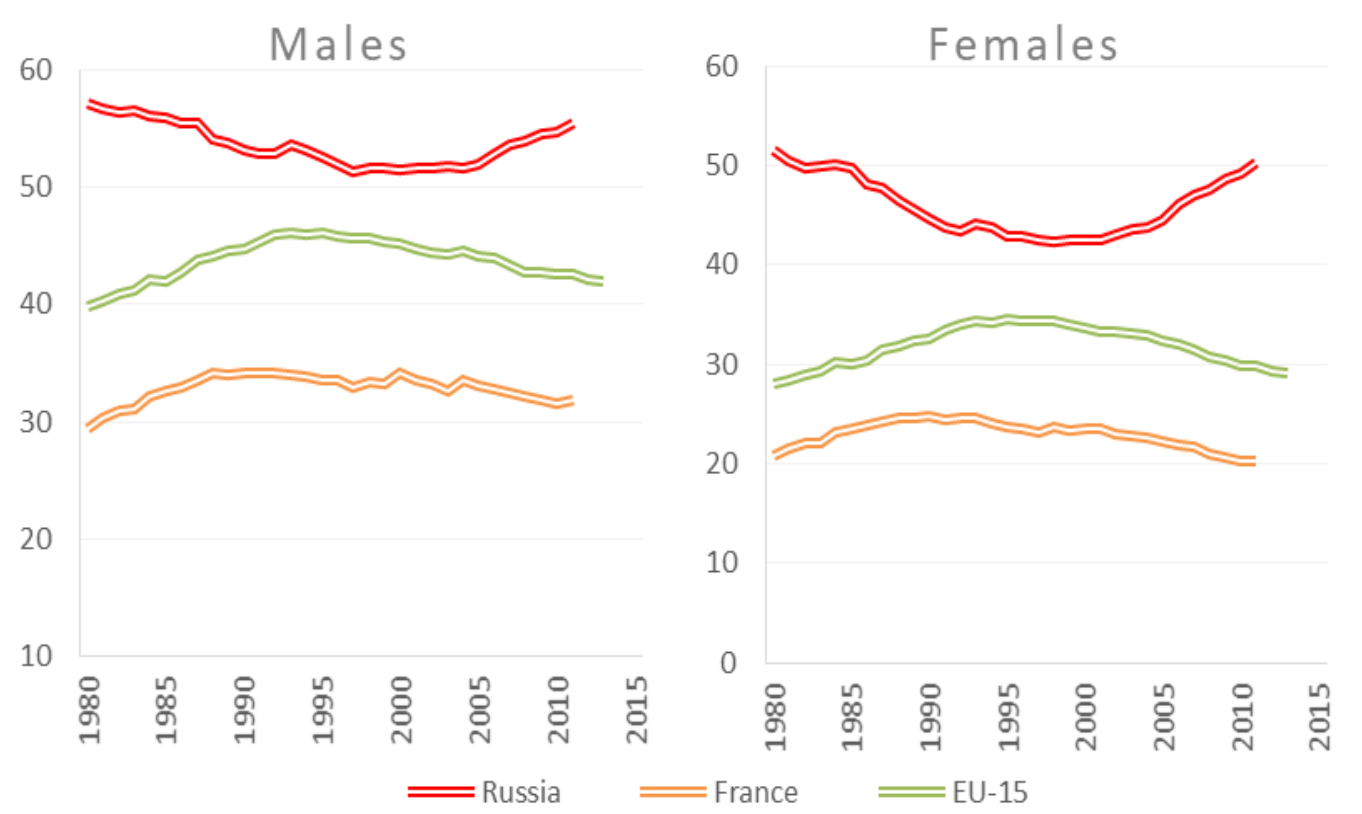

Figure 6. Contribution of ischemic heart disease to the standardized death rate from CVD in Russia, France and the EU-15, \%

Source: Authors' calculations according to [RosBRiS 2015; WHO MD 2015]. 


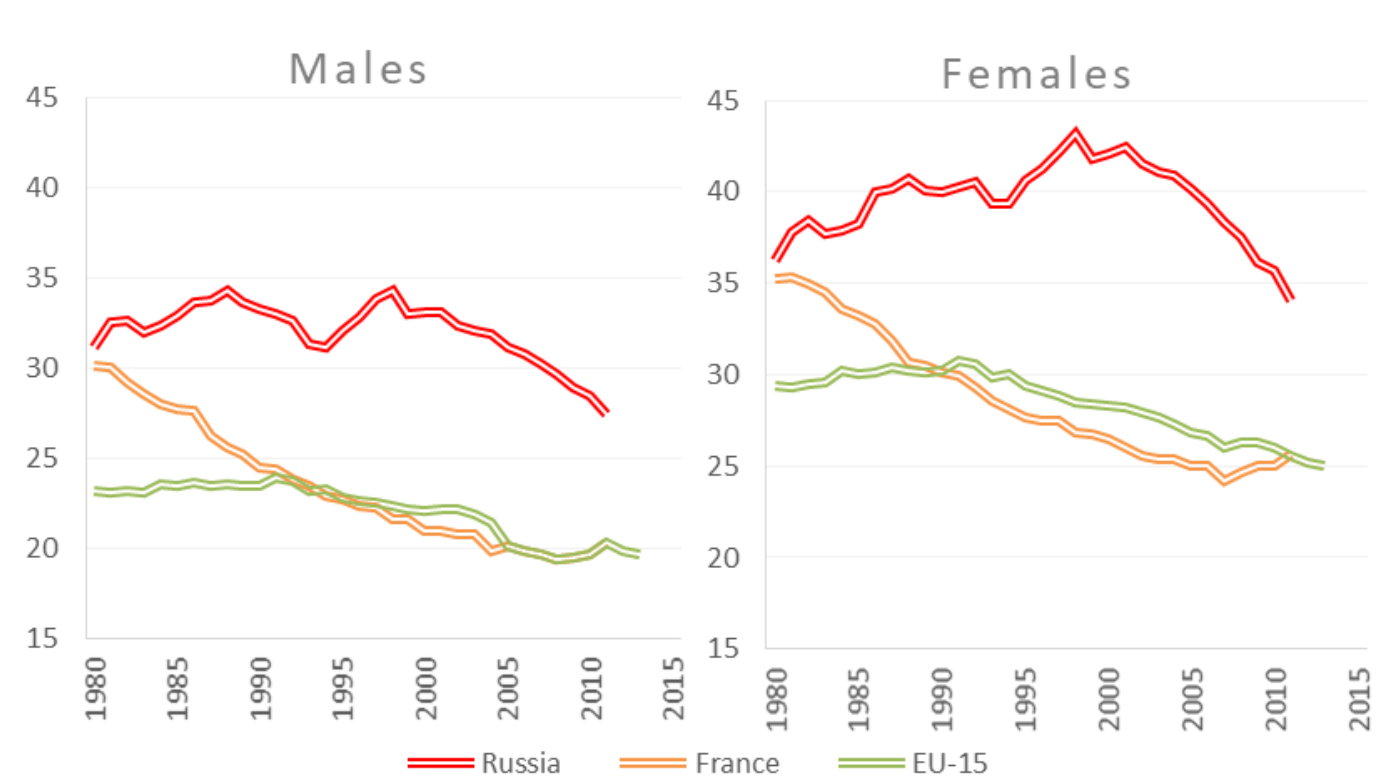

Figure 7. Contribution of cerebrovascular diseases to the standardized death rate from CVD in Russia, France and the EU-15, \%

Source: Authors' calculations according to [RosBRiS 2015; WHO MD 2015].

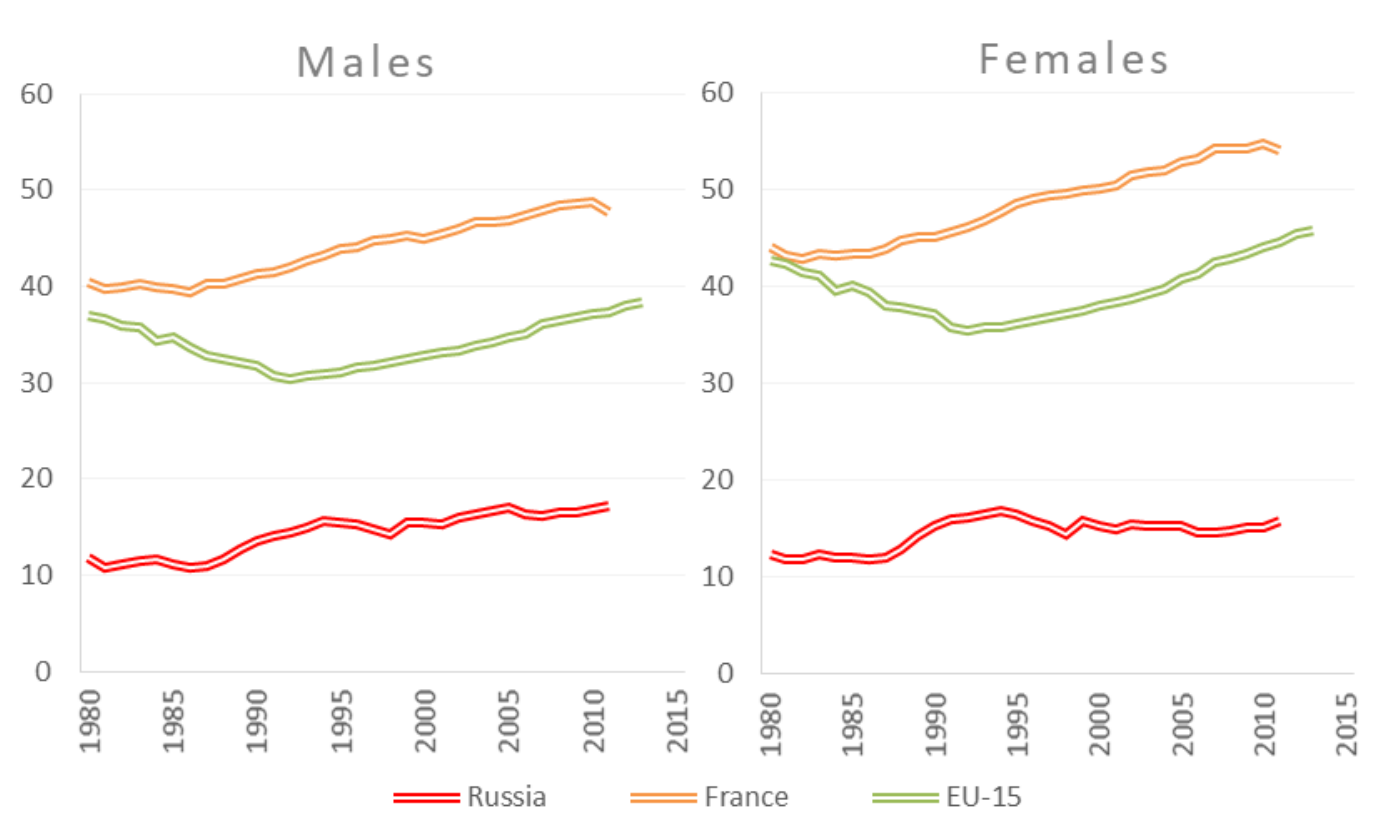

Figure 8. Contribution of other cardiovascular diseases to the standardized death rate from CVD in Russia, France and EU-15 countries, \%

Source: Authors' calculations according to [RosBRiS 2015; WHO MD 2015].

The contribution of the three major groups of causes of death to the total CVD mortality is important not in itself, but in connection with the age at which people die from the diseases of a particular group. In Russia, in comparison with other countries, the average age at death from all three groups of cardiovascular diseases is very low, and, in addition, the ratio between them is not the same as in countries with a low mortality rate. A comparison of Russia and France in Figure 9 shows that in France, the increase in the contribution of other CVD by reducing the contribution of ischemic heart disease and cerebrovascular diseases, as discussed above, is combined with a 
high age at death from other CVD diseases, which in Russia are characterized by much a lower (by 8.5 years in 2010) age at death. At the same time, in Russia the age at death from them for both men and women is significantly lower than from ischemic heart disease or cerebrovascular diseases, while in France it is, on the contrary, the highest.

\section{Males}

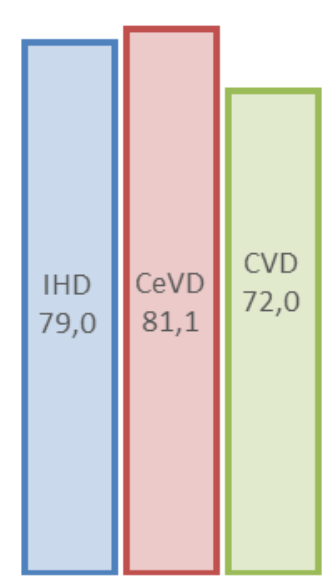

Russia

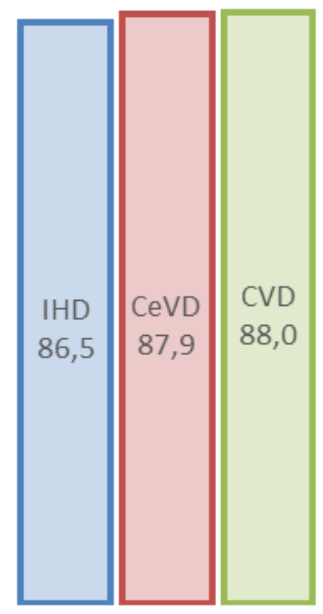

France

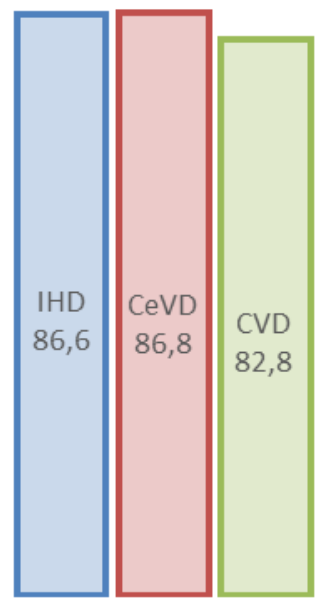

Russia
Females

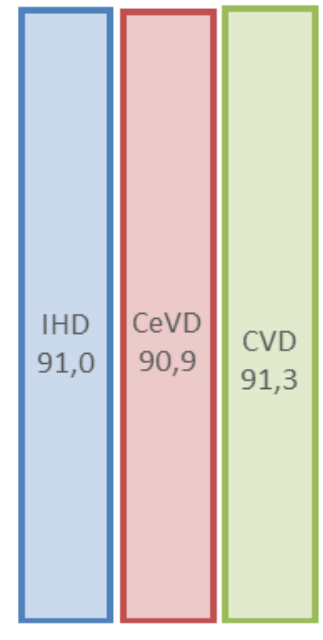

France

Figure 9. The average age at death from ischemic heart disease, cerebrovascular diseases and other CVD diseases in Russia and France, 2010, years

Note: IHD - ischemic heart disease, CeVD - cerebrovascular disease, CVD -cardiovascular diseases.

Source: Authors' calculations according to [RosBRiS 2015; WHO MD 2015].

Table 3 shows that the smallest (though still very significant) gap between Russia and other countries in terms of the average age at death in 2010 was related to cerebrovascular diseases. For mortality from ischemic heart disease, whose contribution is large and tends to be increasing, the gap in the average age at death both is greater and is growing faster than in the case of cerebrovascular diseases. But this gap is especially large for mortality from all other diseases of the circulatory system, especially in men. This feature deserves a separate analysis, which goes beyond the tasks of this article. One can only assume that in Russia this more often concerns those falling into the category of "other" diseases, which are more dependent on conditions and lifestyle, for example, alcoholic cardiomyopathy.

Figure 10 shows the contribution of changes in mortality from CVD diseases and their enlarged groups to changes in life expectancy in Russia from 1972 by the periods of growth and reduction of this indicator. The graph shows that as a result of the mutual cancelling out of these changes, the increase in life expectancy due to the reduction in CVD mortality over the entire more than 40-year period was just over 2 years for women and less than six months for men, and the contribution of cerebrovascular diseases among women, and of other diseases of the circulatory system among men, was, on the whole, negative for the entire period. 
Table 3. The difference in the average age at death from all causes of death and from CVD between Russia and some countries, years *

\begin{tabular}{|c|c|c|c|c|c|c|c|c|}
\hline & Germany & Poland & USA & France & Sweden & Estonia & Czechia & Finland \\
\hline \multicolumn{9}{|c|}{ Men } \\
\hline \multicolumn{9}{|c|}{ All causes of death } \\
\hline 1970 & 0.66 & -0.05 & 0.43 & 1.93 & 3.99 & 1.27 & - & -2.35 \\
\hline 1990 & 5.02 & 0.37 & 4.94 & 6.43 & 6.27 & 0.24 & 0.47 & 2.67 \\
\hline 2010 & 11.48 & 5.41 & 9.95 & 12.62 & 12.72 & 5.67 & 8.89 & 10.21 \\
\hline \multicolumn{9}{|c|}{ Ischemic heart disease } \\
\hline 1970 & -2.67 & -5.06 & -0.56 & -2.24 & 3.32 & 1.21 & - & -5.06 \\
\hline 1990 & 4.43 & -5.67 & 5.86 & 5.05 & 6.25 & 2.00 & 0.14 & 3.16 \\
\hline 2010 & 10.10 & 3.05 & 9.15 & 10.28 & 11.25 & 6.19 & 8.16 & 10.29 \\
\hline \multicolumn{9}{|c|}{ Cerebrovascular diseases } \\
\hline 1970 & 2.24 & -2.28 & 2.24 & 2.41 & 3.85 & 1.01 & - & -0.74 \\
\hline 1990 & 4.99 & -3.74 & 4.93 & 5.67 & 5.57 & -0.82 & 0.56 & 2.19 \\
\hline 2010 & 8.98 & 1.94 & 8.00 & 9.78 & 10.24 & 3.00 & 7.18 & 8.14 \\
\hline \multicolumn{9}{|c|}{ Other CVD diseases } \\
\hline 1970 & 6.20 & 5.81 & 4.31 & 7.10 & 8.66 & 0.17 & - & 5.49 \\
\hline 1990 & 6.83 & 4.35 & 5.13 & 8.29 & 8.93 & -8.32 & 2.11 & 3.94 \\
\hline \multirow[t]{2}{*}{2010} & 19.00 & 13.41 & 16.71 & 20.40 & 20.53 & 10.70 & 15.19 & 14.20 \\
\hline & & & & Women & & & & \\
\hline \multicolumn{9}{|c|}{ All causes of death } \\
\hline 1970 & -0.02 & -1.18 & 1.31 & 1.34 & 2.54 & 1.07 & - & -1.18 \\
\hline 1990 & 3.53 & 0.17 & 4.00 & 5.39 & 4.59 & 0.34 & -0.17 & 2.42 \\
\hline 2010 & 7.03 & 3.75 & 5.54 & 8.90 & 7.65 & 4.89 & 4.89 & 7.26 \\
\hline \multicolumn{9}{|c|}{ Ischemic heart disease } \\
\hline 1970 & -2.35 & -3.89 & 0.30 & -2.27 & 1.77 & 1.01 & - & -3.37 \\
\hline 1990 & 2.02 & -6.38 & 3.84 & 3.81 & 3.46 & 0.94 & -0.93 & 1.62 \\
\hline 2010 & 6.22 & 2.63 & 5.16 & 8.04 & 6.55 & 5.46 & 4.90 & 7.35 \\
\hline \multicolumn{9}{|c|}{ Cerebrovascular diseases } \\
\hline 1970 & 0.94 & -2.79 & 2.13 & 1.81 & 1.93 & 0.57 & - & -1.26 \\
\hline 1990 & 3.99 & -3.00 & 4.55 & 5.50 & 4.82 & 0.16 & 0.35 & 2.74 \\
\hline 2010 & 5.63 & 1.34 & 4.80 & 7.40 & 6.58 & 3.03 & 4.34 & 5.89 \\
\hline \multicolumn{9}{|c|}{ Other CVD diseases } \\
\hline 1970 & 4.01 & 3.31 & 4.00 & 5.97 & 6.48 & -0.45 & - & 4.15 \\
\hline 1990 & 4.81 & 2.19 & 4.00 & 6.52 & 6.28 & -8.06 & 0.59 & 3.87 \\
\hline 2010 & 11.24 & 8.36 & 9.18 & 13.09 & 12.15 & 7.69 & 7.81 & 10.34 \\
\hline
\end{tabular}

*The average age is taken from multiple life tables and does not depend on the population age structure. Positive values in Table 3 indicate how many years less the average age at death is in Russia than in the specified country, negative values - by how many it is greater.

Source: Authors' calculations according to [RosBRiS 2015; WHO MD 2015]. 


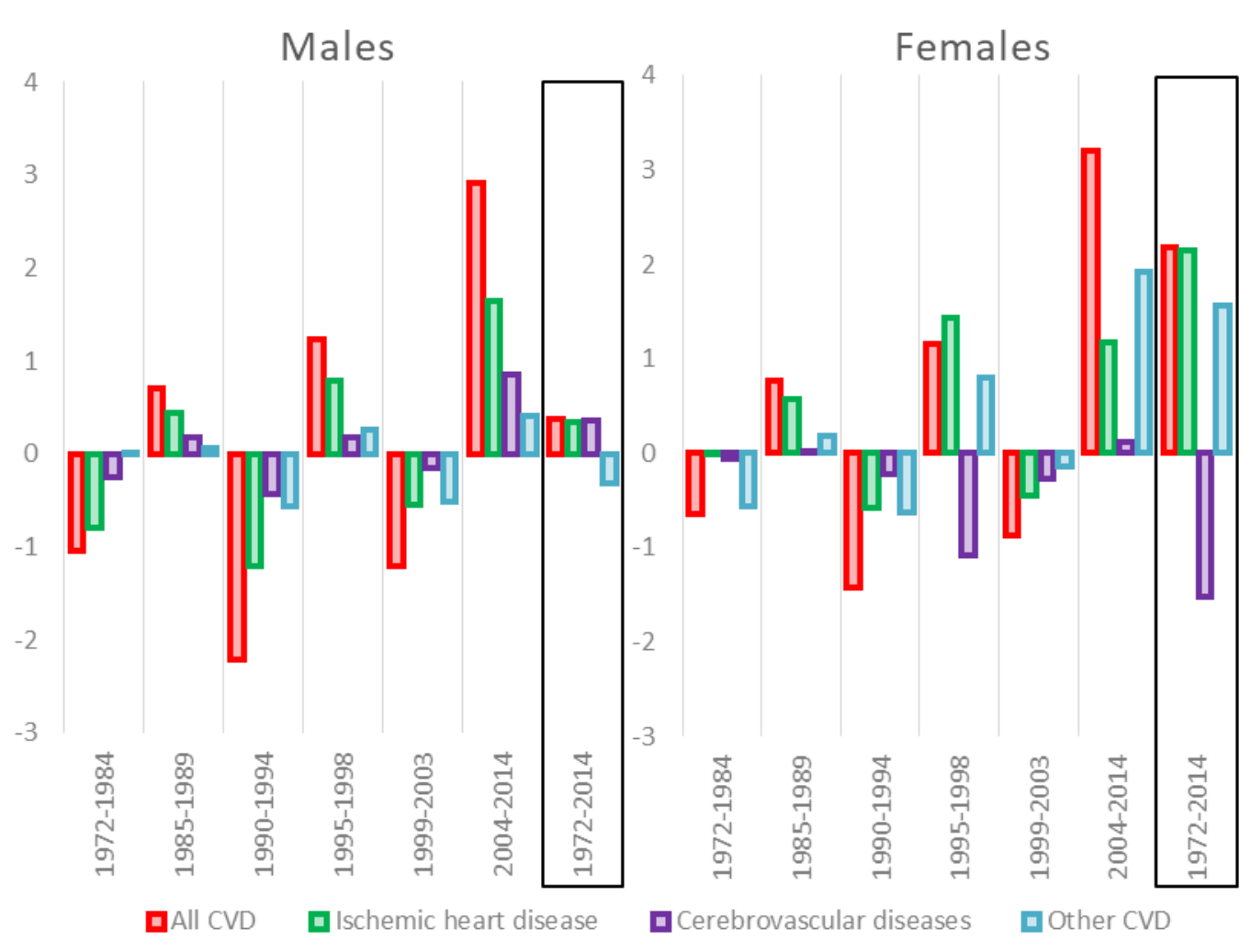

Figure 10. Changes in life expectancy at birth in Russia as a result of changes in CVD mortality and its separate groups for 1972-2014, years

Source: Authors' calculations according to [RosBRiS 2015; WHO MD 2015].

\section{THE AGE-SPECIFIC PATTERNS OF CARDIOVASCULAR MORTALITY IN RUSSIA}

The low age at death from CVD diseases and their enlarged groups in Russia is evidence of a general stagnation in the age-specific mortality pattern. Both the pattern itself and its dynamics in Russia are strikingly different from what can be seen in the last few decades in the countries of the "cardiovascular revolution", in particular in the countries of Western Europe (Figure 11).

As follows from Figure 11, among men in Russia the table number of deaths $\left(d_{x}\right)$ from cardiovascular diseases begins to grow rapidly after the age of 25 . The bulk of deaths from these causes is concentrated in the ages of up to 70 -75 years, after which their share even goes down. In Western Europe, growth begins later (Russian indicators recorded at age 25 there are not reached even by age 40) and the curves rise much less steeply, but this rise lasts to the latest ages, so that the peak of deaths from diseases of the circulatory system is not, as in Russia, between 7075 years, but closer to 90 years. On our graph, where the age scale ends with an open age interval of 85 years and older, the maximum number of deceased men and women in the EU-15 falls in this open age interval. Among Russian women, the age distribution of deaths from cardiovascular diseases is more similar to that of Western Europe, but is still strongly shifted towards younger ages. 


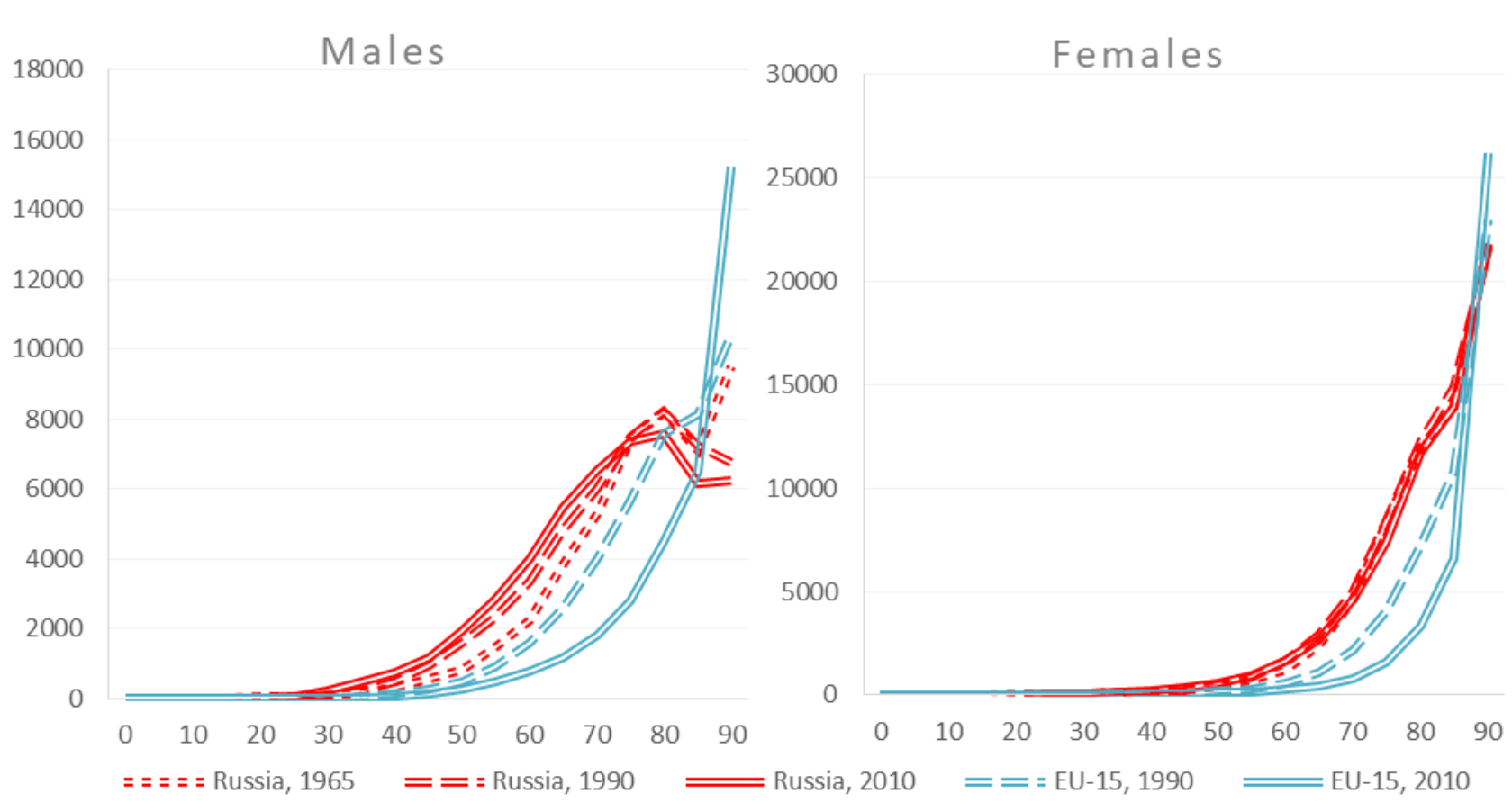

Figure 11. Age-specific pattern of table numbers of deaths $\left(d_{x}\right)$ from cardiovascular diseases in Russia and in EU-15 countries, per 100,000

Source: Authors' calculations according to [RosBRiS 2015; WHO MD 2015].

What's more, the curves for the EU-15 countries show a pronounced tendency to shift down and to the right, "bending" towards the lower right corner of the chart. When comparing the curves of 1990 and 2010, it is clearly seen that the right end of the 2010 curves for both men and women turns confidently up, indicating the displacement of an increasing number of deaths from cardiovascular diseases to later ages. In Russia, for men, the curves are generally not bent to the right, but to the left, indicating a high mortality rate in middle age, while the 2010 curve is worse than the 1990 curve, which in turn is worse than the curve of 1965. The curves for women are closer to those of Western Europe, but also strongly shifted to the left. At the same time, they show neither the rightward shift of European curves, indicative of progress, nor the leftward shift indicative of regress, as in the curves for Russian men - rather, one can speak of complete stagnation for almost five decades.

Figure 12 shows the dynamics in Russia of age-specific death rates from cardiovascular diseases for the 4 age groups most susceptible to death from them since 1970. It can be seen that the largest variations in cardiovascular mortality are characteristic for younger ages, whereas older age groups are less susceptible to such fluctuations.

Despite a significant reduction in mortality in all age groups over the past 10 years, the level of male mortality from CVD at ages of up to 75 years, and of female mortality up to 45 years, is still higher than that reached in 1970. 


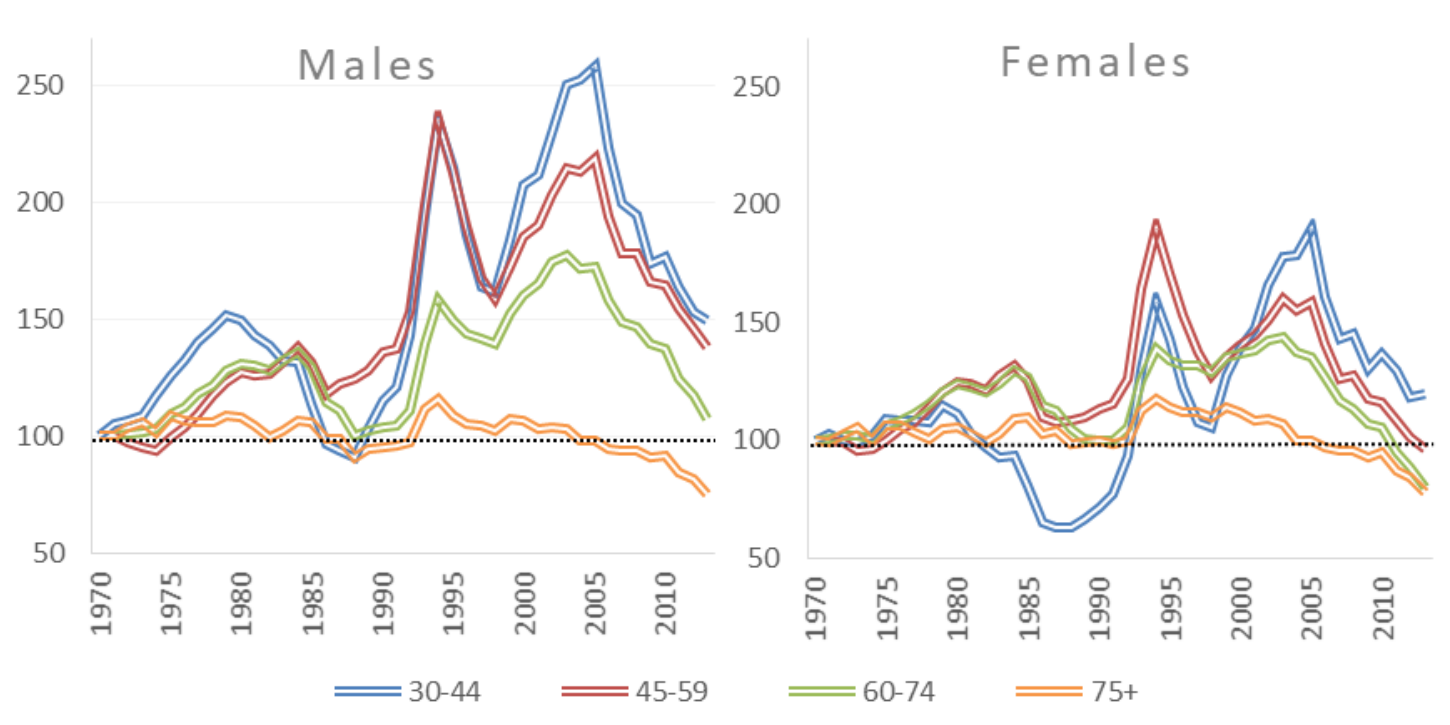

Figure 12. Changes of the age-specific death rates (at ages 30-44, 45-59, 60-74 and 75+) from cardiovascular diseases, $1970=100 \%$

Source: Authors' calculations according to [RosBRiS 2015].

Table 4. Excess table numbers of male and female deaths $\left(d_{x}\right)$ from cardiovascular diseases at age 30-85 years in Russia in comparison with some countries, per 100,000

\begin{tabular}{|c|c|c|c|c|c|c|c|c|c|c|}
\hline & \multicolumn{5}{|c|}{ Men } & \multicolumn{5}{|c|}{ Women } \\
\hline & $\begin{array}{l}\text { Japan, } \\
2013\end{array}$ & $\begin{array}{c}\text { France, } \\
2011\end{array}$ & $\begin{array}{l}\text { USA, } \\
2010\end{array}$ & $\begin{array}{c}\text { Czech } \\
\text { Republic, } \\
2013\end{array}$ & $\begin{array}{c}\text { Estonia, } \\
2012\end{array}$ & $\begin{array}{l}\text { Japan, } \\
2013\end{array}$ & $\begin{array}{c}\text { France, } \\
2011\end{array}$ & $\begin{array}{l}\text { USA, } \\
2010\end{array}$ & $\begin{array}{c}\text { Czech } \\
\text { Republic, } \\
2013\end{array}$ & $\begin{array}{c}\text { Estonia, } \\
2012\end{array}$ \\
\hline $30-34$ & 361 & 373 & 320 & 346 & 322 & 105 & 108 & 80 & 112 & 104 \\
\hline $35-39$ & 591 & 617 & 533 & 604 & 449 & 182 & 183 & 134 & 169 & 123 \\
\hline $40-44$ & 862 & 904 & 757 & 827 & 591 & 275 & 284 & 197 & 260 & 247 \\
\hline $45-49$ & 1334 & 1404 & 1115 & 1181 & 870 & 406 & 430 & 268 & 362 & 322 \\
\hline $50-54$ & 1979 & 2037 & 1608 & 1631 & 1034 & 602 & 624 & 385 & 484 & 507 \\
\hline $55-59$ & 2822 & 2879 & 2281 & 2000 & 1441 & 1112 & 1146 & 803 & 873 & 743 \\
\hline $60-64$ & 4031 & 4147 & 3377 & 2488 & 1427 & 1931 & 1985 & 1447 & 1338 & 1208 \\
\hline $65-69$ & 4333 & 4481 & 3458 & 1915 & 816 & 3013 & 3112 & 2284 & 1783 & 1717 \\
\hline $70-74$ & 5520 & 5636 & 4434 & 2408 & 1166 & 5738 & 5758 & 4670 & 3396 & 3061 \\
\hline $75-79$ & 4619 & 4664 & 3434 & 434 & -2 & 8076 & 8123 & 6681 & 3909 & 2900 \\
\hline $80-84$ & 2036 & 2059 & 1131 & -2300 & -1715 & 9199 & 9166 & 7965 & 1962 & 386 \\
\hline Total: & 28489 & 29200 & 22449 & 11536 & 6399 & 30639 & 30918 & 24915 & 14648 & 11318 \\
\hline & nber of e. & deaths. & & over 5000 & & -5000 & 1000 & 3000 & fewer th & 1000 \\
\hline
\end{tabular}

Source: Authors' calculations according to [RosBRiS 2015; WHO MD 2015]

The shortcomings of the age-specific pattern of Russian mortality from CVD are clearly visible in Table 4, which allows us to compare the distribution of deaths by age in Russia and some other countries and identify "age risk groups" for the population of Russia, indicating for each of them by how much the number of deaths is excessive in comparison with these countries.

For example, the figure in the bottom line of column 2 of Table 4 shows that in 2013, in Russia, compared to Japan, out of every 100,000 male deaths at all ages, more than 28,000 deaths occurring at the ages 30-84 years old from CVD could be considered excessive - in Japan they would not have occurred at these ages. Moreover, the number of excess deaths at the age of 70-74 is particularly high, while the excess mortality at ages of up to 45 years, although it exists at these ages, is still relatively small. In the same way, you can analyze any column of the table. 


\section{REGIONAL FEATURES OF CARDIOVASCULAR MORTALITY}

An analysis of CVD mortality in Russia cannot be complete without consideration of the regional features that manifest themselves against the background of the general picture characteristic of the whole country.

The most unfavorable situation in 2013 was in the regions of the Far East, some regions of Eastern Siberia (Tyva, Irkutsk oblast, Yamalo-Nenets autonomous district), and in the north and northwest of the European part of Russia and the Urals (Perm kray). On the contrary, the regions with the lowest mortality from CVD diseases are cities of federal significance (Moscow and St. Petersburg), the south of the European part of Russia, the Volga region and some regions of Western Siberia (Figures 13 and 14).

Figures 15 and 16 show the changes in the standardized death rates from CVD of men and women in the regions of Russia. Over the decade from 2003 to 2013 these changes were positive in all Russian regions, although their magnitude varied from region to region. In general, the standardized death rate from cardiovascular diseases in Russia decreased by $36.3 \%$ in men and by $37.8 \%$ in women. The highest rates of mortality reduction were primarily recorded in those regions that in 2003 had the highest mortality rates from diseases of the circulatory system, mainly the regions around Moscow and St. Petersburg. Some of these regions managed to significantly improve their relative positions by 2013 (Ivanovo, Smolensk, Leningrad, Lipetsk, Kursk and Tambov regions). At the same time, we note a sharp increase in all these areas (with the exception of the Leningrad Region) in the share of deaths from senility of persons over 80, which may be indicative not so much of real progress in reducing cardiovascular mortality as of changes in regional practices of coding the causes of death (for more details see below). High rates of reduction in mortality from diseases of the circulatory system were observed in Moscow and St. Petersburg, which further strengthened their positions. Modest rates of mortality reduction from CVD were found in a number of regions of the Far East (Chukotka Autonomous District, Sakha Republic, Magadan Oblast and the Jewish Autonomous Region) and Siberia (YNAO, Altai Republic, Novosibirsk and Omsk Regions). 


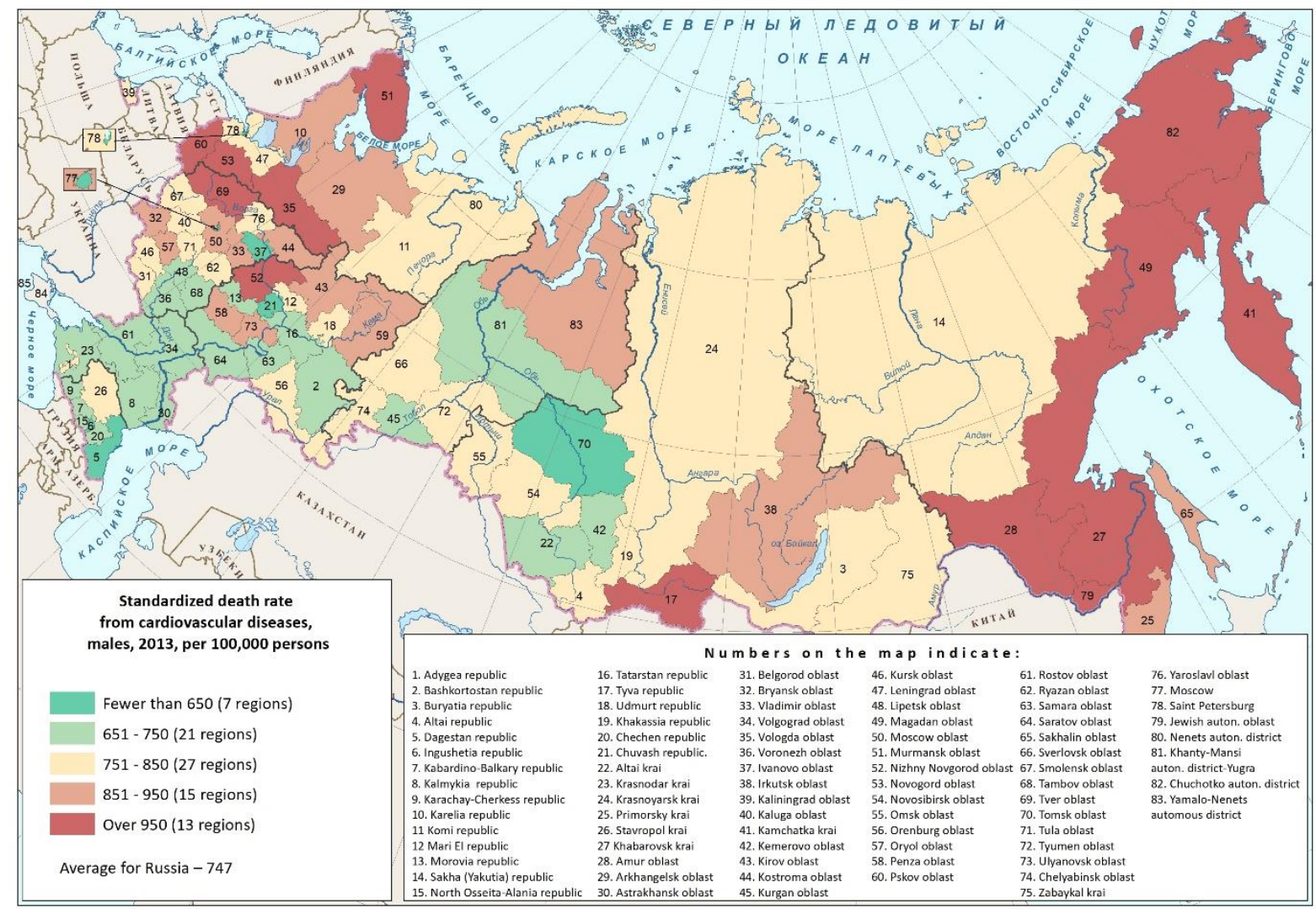

Figure 13. Mortality from cardiovascular diseases, males, 2013

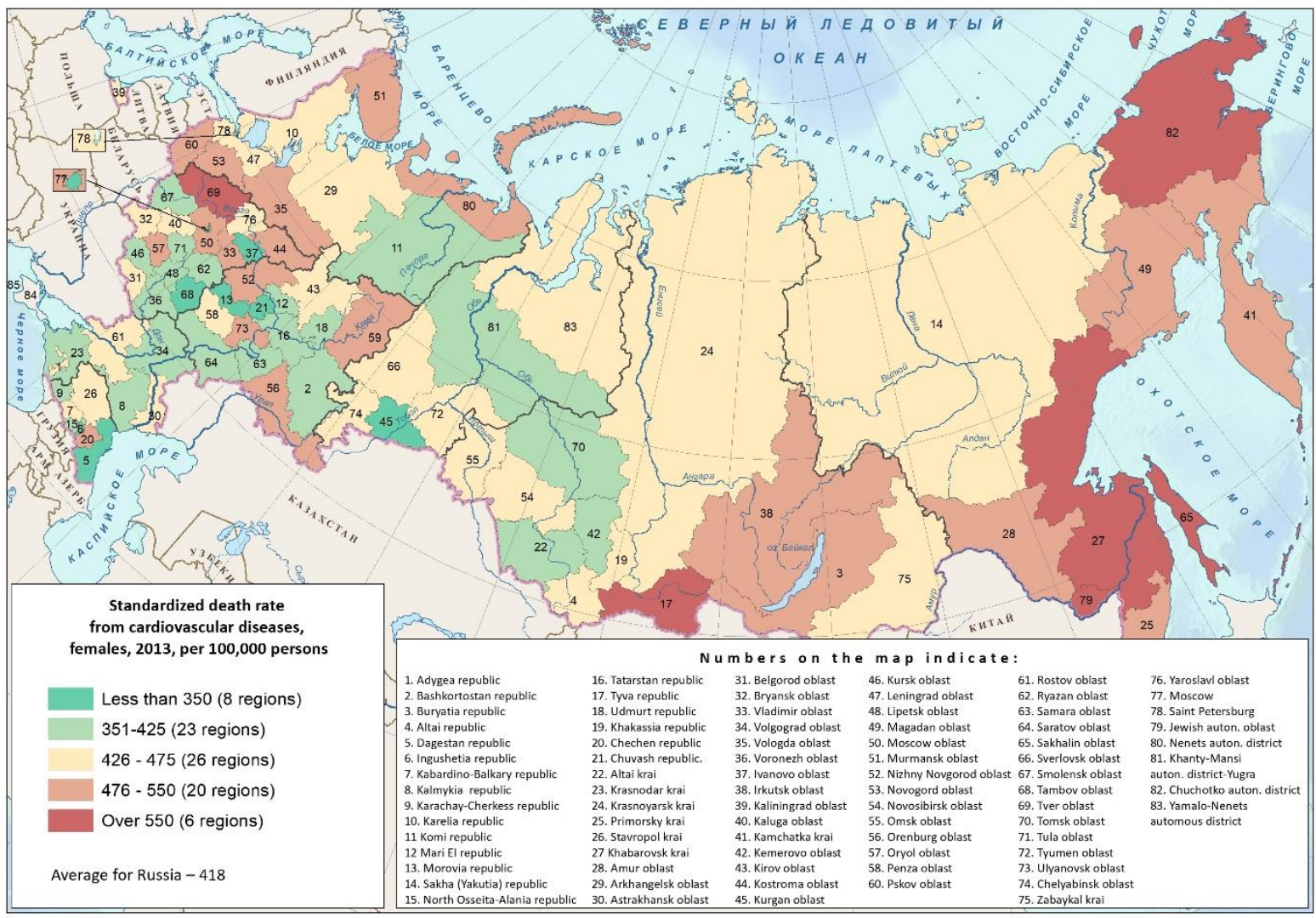

Figure 14. Mortality from cardiovascular diseases, females, 2013 


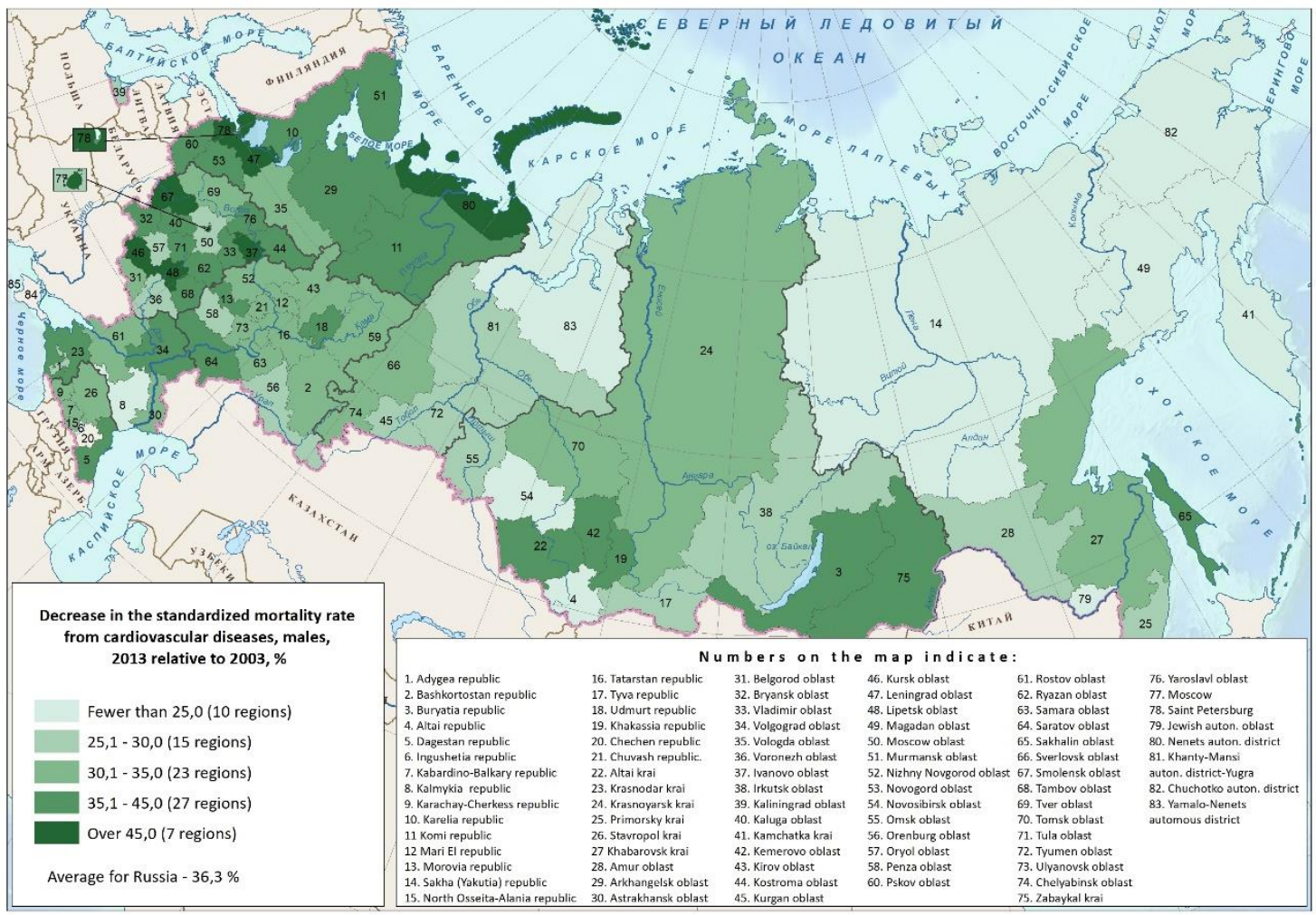

Figure 15. Changes in cardiovascular mortality, males, 2003-2013

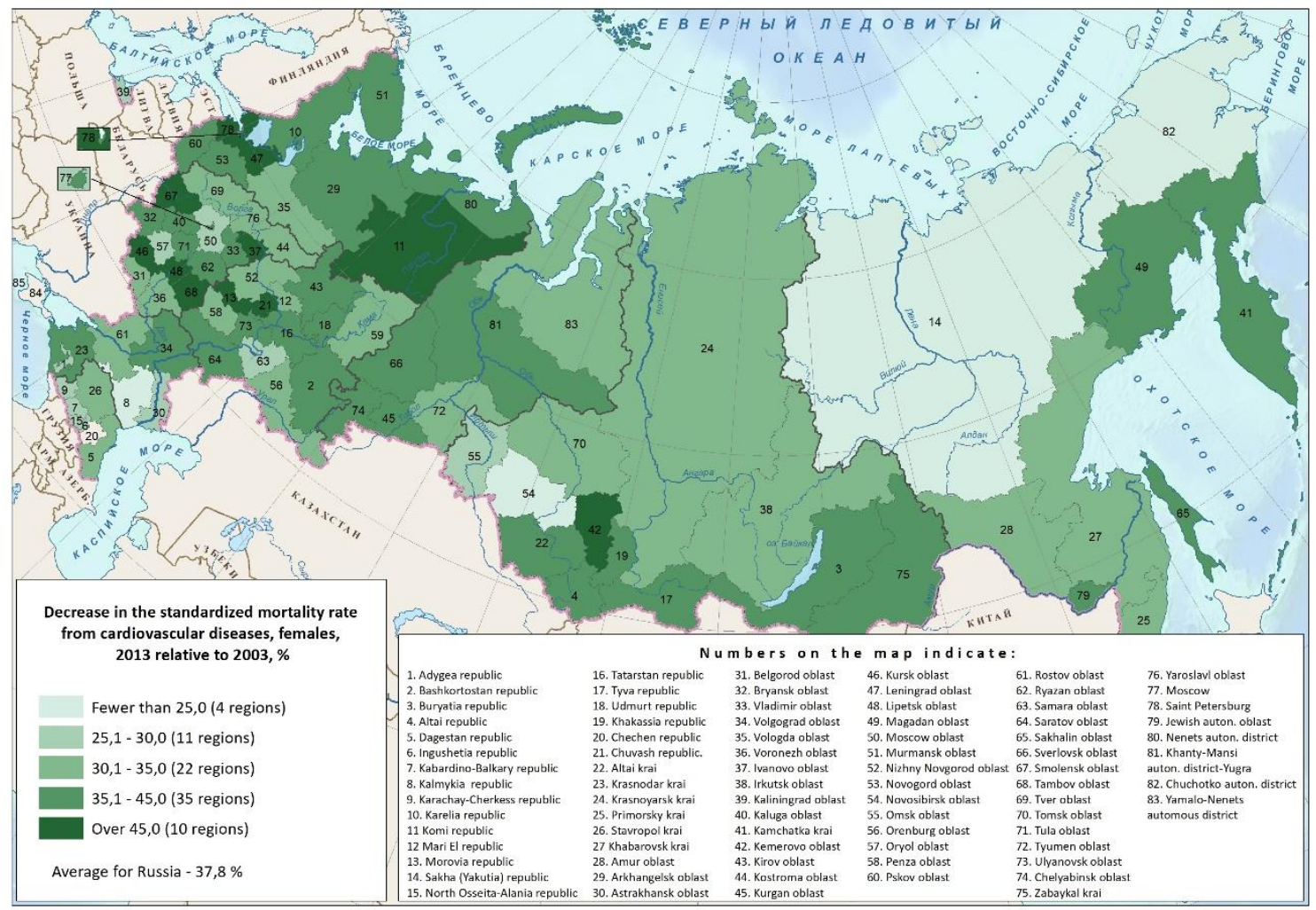

Figure 16. Changes in cardiovascular mortality, females, 2003-2013 


\section{HYPERDIAGNOSIS OR AN UNDERESTIMATE OF CARDIOVASCULAR MORTALITY?}

The possibilities of analyzing the level and trends of mortality from diseases of the circulatory system depend significantly on the quality of the coding of the causes of death when filling out the medical certificate of death. This quality in Russia is far from flawless.

Often, those dying at older ages had several diseases, each of which in some way could have led to death. In the process of preparing a medical certificate of death, which is the main source of statistical information, the physician must choose from an aggregate of possible causes the underlying one. For these purposes, relevant recommendations have been developed both at the federal level and in the regions. In addition to recommendations, there is the opinion of the doctor and the practice of diagnosis and coding - the doctor often chooses not the most "correct", but the most common diagnosis, which does not raise questions among the relatives of the deceased or the management of the medical institution. In Russia, diseases of the circulatory system, considered a natural cause of death in old age, long remained such a diagnosis, thus giving the expert community reason to talk about the overdiagnosis of cardiovascular causes of death. Instructions on "cardiological padding" are still found today [Kakorina 2013].

At the same time, there is also reason to fear an underestimate of cardiovascular mortality. In March 1989, the Board of the Ministry of Health of the USSR, in order to combat the high mortality from cardiovascular diseases, on the initiative of the Minister E.I. Chazova adopted "Instructions on the procedure for determining the cause of death in the main diseases of the circulatory system and recording in the medical certificate of death." The fifteenth paragraph of the "Instructions ..." reads as follows: "For deaths occurring outside the hospital at the age of more than 80 years, in the absence of evidence in the medical documentation of diseases capable of causing death, in the absence of suspicion of violent death, and in cases when pathoanatomical research was not conducted, a certificate of death from a doctor or medical assistant shall be issued indicating "senility" as the cause of death." Note that the diagnosis of " senility " is allowed only after age 80, and this cause of death belongs to the class "Symptoms, signs and abnormalities found in clinical and laboratory studies, not classified elsewhere", which essentially means that the exact cause of death is not established.

Growth in the number of deaths and in the mortality ratio due to senility was not long in coming (Figure 17). By the mid-2000s, the indication "senility" as the original cause of death had become much rarer, but, as it turned out, not for long. In the last few years, especially since 2012, the number of deaths diagnosed as from senility has been steadily increasing, in unison with a decline in mortality from diseases of the circulatory system in people over 80 . For example, in $2012,11.8 \%$ of those dying at the age of 80 and older died with the diagnosis "senility", while $72.3 \%$ died of cardiovascular diseases. By 2014, the share of deaths from "senility" was already $18.7 \%$ (up 6.9 percentage points), and from cardiovascular diseases - 61.2\% (down $11.1 \mathrm{pp).}$ 


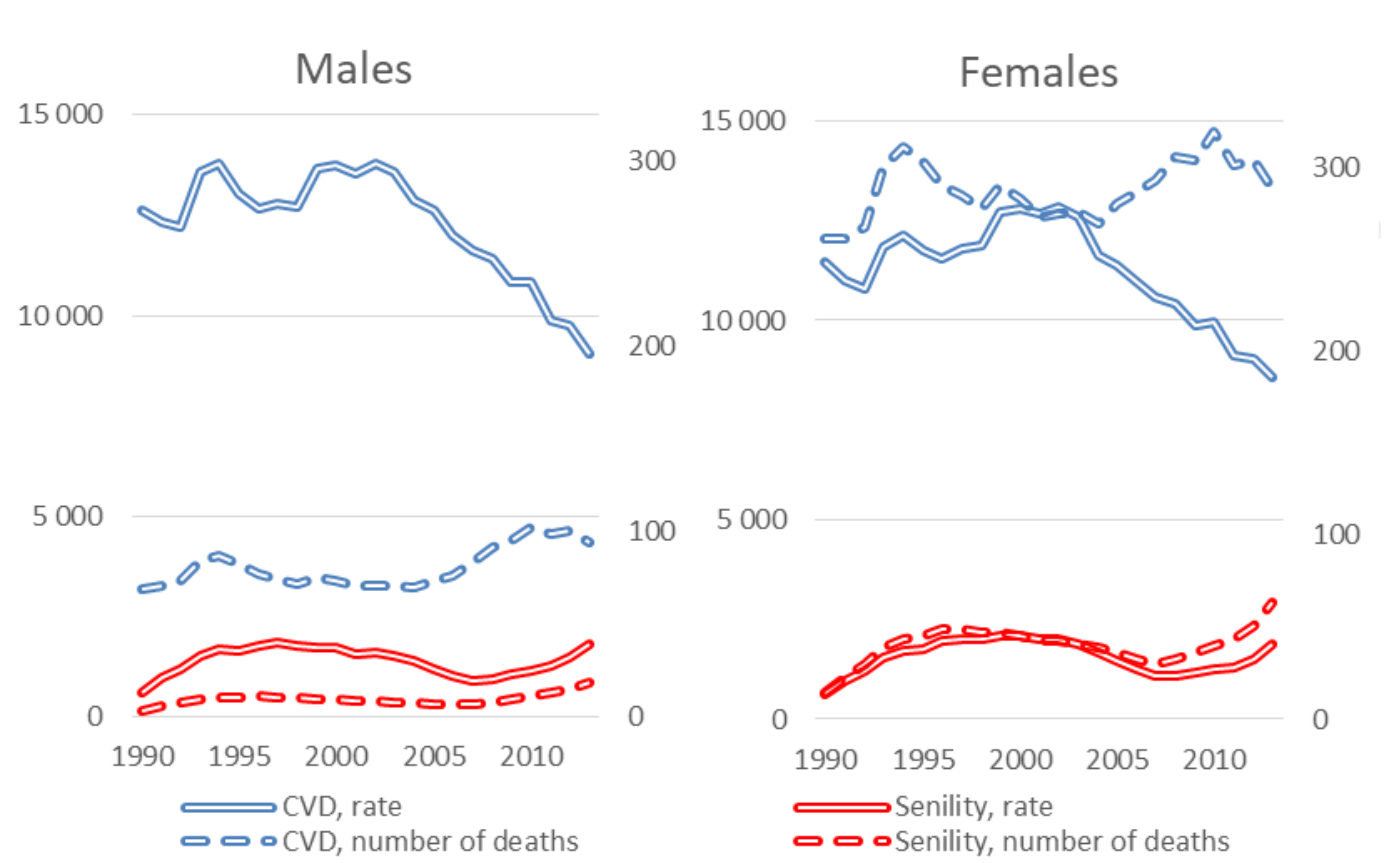

Figure 17. Mortality rates from CVD and "senility" at the age of 80 years and older, per 100,000 people (left axis) and the absolute number of deaths from CVD and "senility" at the age of 80 years and older, thousand people (right axis)

An analysis of mortality by cause of death in recent years shows that the Presidential Decree "On Improving Public Health Policy", aimed at reducing the overall mortality rates from a number of causes of death, including from diseases of the circulatory system, can lead to the fact that some regions of the Russian Federation, in striving to achieve target mortality, change the practice of coding the causes of death, as we have already had occasion to discuss [Vishnevsky, Andreev, Timonin 2015].

The decree was issued in May 2012. From 2012 to 2014, the total number of deaths in Russia decreased by $1.5 \%$. This decrease did not affect all regions; in some of them the number of deaths increased. The corresponding indicator for the regions varies from $-15 \%$ in the Nenets Autonomous District and $-8.7 \%$ in the Magadan Region to 3.5\% in the Khanty-Mansiysk Autonomous District - Ugra. If we exclude regions with extreme indicators, then in 77 out of 83 regions the changes lie in the range from $-9 \%$ to $2 \%$. But the situation with cardiovascular diseases looks different. In Russia, the total number of deaths from them decreased by $10.9 \%$, while the number of deaths from all other causes increased by $10.2 \%$. If we turn to regional indicators, it is striking that the greatest decrease in the number of deaths from cardiovascular diseases is observed where mortality from other causes increased despite almost no change in the total number of deaths (table 5).

In Moscow and St. Petersburg the number of deaths from cardiovascular diseases decreased by 3.0 and $7.2 \%$, and from other causes increased by 3.4 and $3.6 \%$, respectively. 
Table 5. The change in the number of deaths from all causes of death, from cardiovascular diseases and from all other causes of death, 2012-2014, \%

\begin{tabular}{|c|c|c|c|}
\hline & All causes & $\begin{array}{c}\text { Cardiovascular } \\
\text { diseases }\end{array}$ & All other causes \\
\hline Rostov region & 0.2 & -31.4 & 52.7 \\
\hline Belgorod region & 0.0 & -20.8 & 45.2 \\
\hline Mariy El republic & -0.4 & -30.3 & 33.2 \\
\hline Vladimir region & -2.0 & -22.2 & 31.4 \\
\hline Yaroslav region & -2.2 & -23.8 & 28.4 \\
\hline Bryansk region & -2.9 & -25.9 & 38.9 \\
\hline Tula region & -4.8 & -30.1 & 31.2 \\
\hline
\end{tabular}

The number of deaths from "senility" grew too. The proportion of deaths with this diagnosis increased between 2012 and 2014 from 11.8 to $18.7 \%$, and varied enormously by region (Figures 18a and 18b). In Bashkortostan and Mordovia, the cause of more than half of the deaths among those over 80 years old was classified this way. In St. Petersburg, this diagnosis was not found, while in Moscow the proportion of people who died of senility was less than $0.1 \%$. But in 20 regions of the Russian Federation, the proportion of those who died of senility at the age of 80 and older in 2012 exceeded 20\%. In 2014, the number of such territories increased to 31. In the Kostroma, Sverdlovsk, Bryansk, Belgorod and Rostov regions, the percentage of deaths with the diagnosis of diagnosis of senility increased from 21 to 49 percentage points, and the decrease in the proportion of deaths with cardiovascular diagnosis was 22 to 49 points. In the Altai Republic, Khanty-Mansiysk Autonomous Okrug, Perm Krai, Orenburg, Amur, Astrakhan oblasts, the percentage of deaths with the diagnosis of senility increased from 12 to 21 percentage points, and the proportion of cardiovascular diagnoses decreased from 9 to 21 percentage points.

The response of the Ministry of Health of the Russian Federation to this "unexpected" increase in mortality from "senility" was a letter sent at the end of 2014 to the heads of executive bodies in the Russian Federation in the field of health care, explaining that the term "senility" refers to inaccurately indicated conditions, and that criteria for its use as the underlying cause of death are: "Age over 80 years, the absence of evidence in the medical records of chronic diseases, injuries and their consequences capable of causing death, the absence of suspicion of violent death."

The existence in the recent past of overdiagnosis of circulatory diseases as a cause of death is very likely. It is possible that the regions, in their attempts to achieve target mortality indicators, try to get rid of the phenomenon and change the practice of coding the causes of death. But it is not at all clear to what extent such radical changes are justified. In total, the number of deaths from diseases of the circulatory system decreased over 2 years by $15 \%$ or more in 19 regions. 


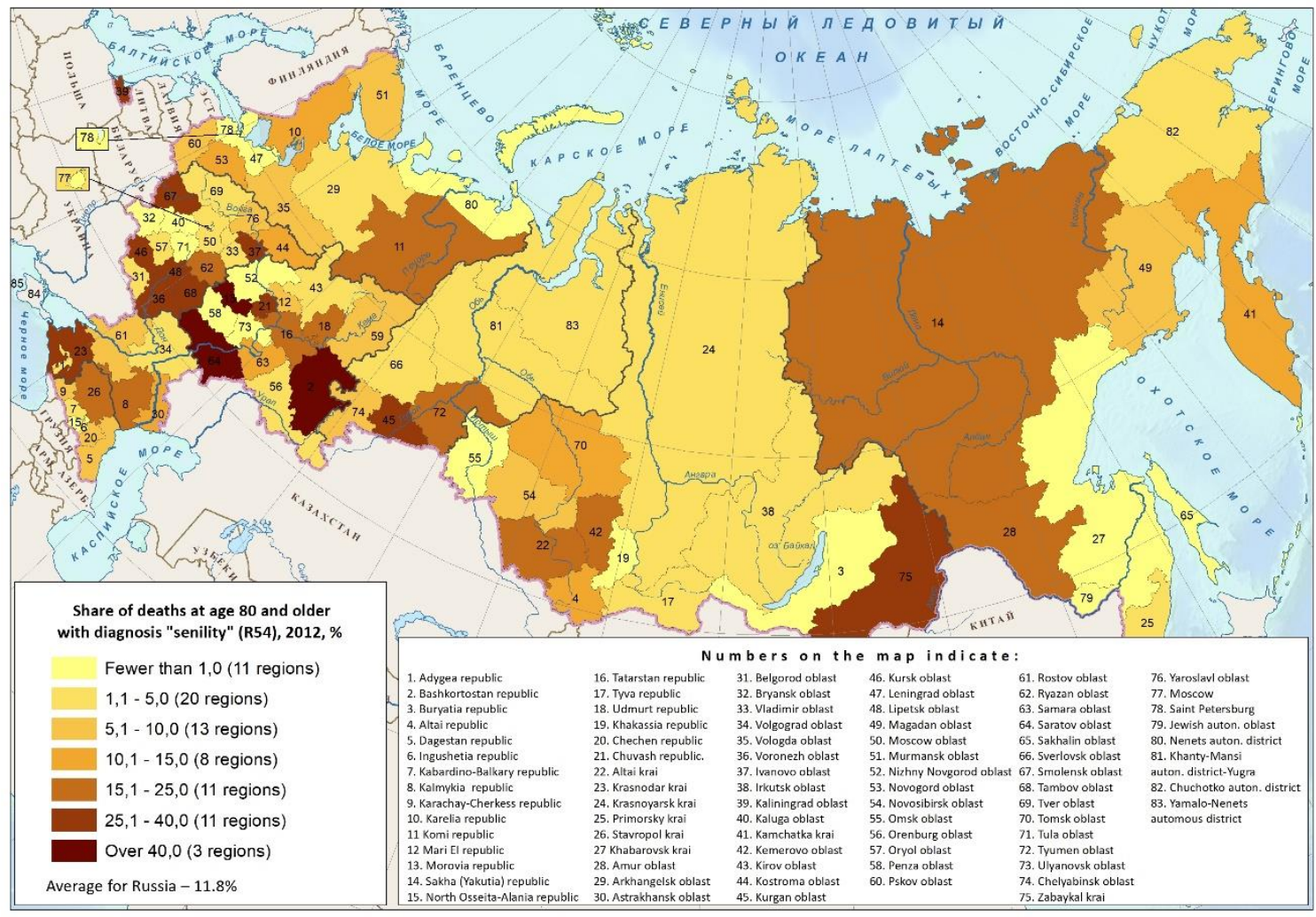

2012

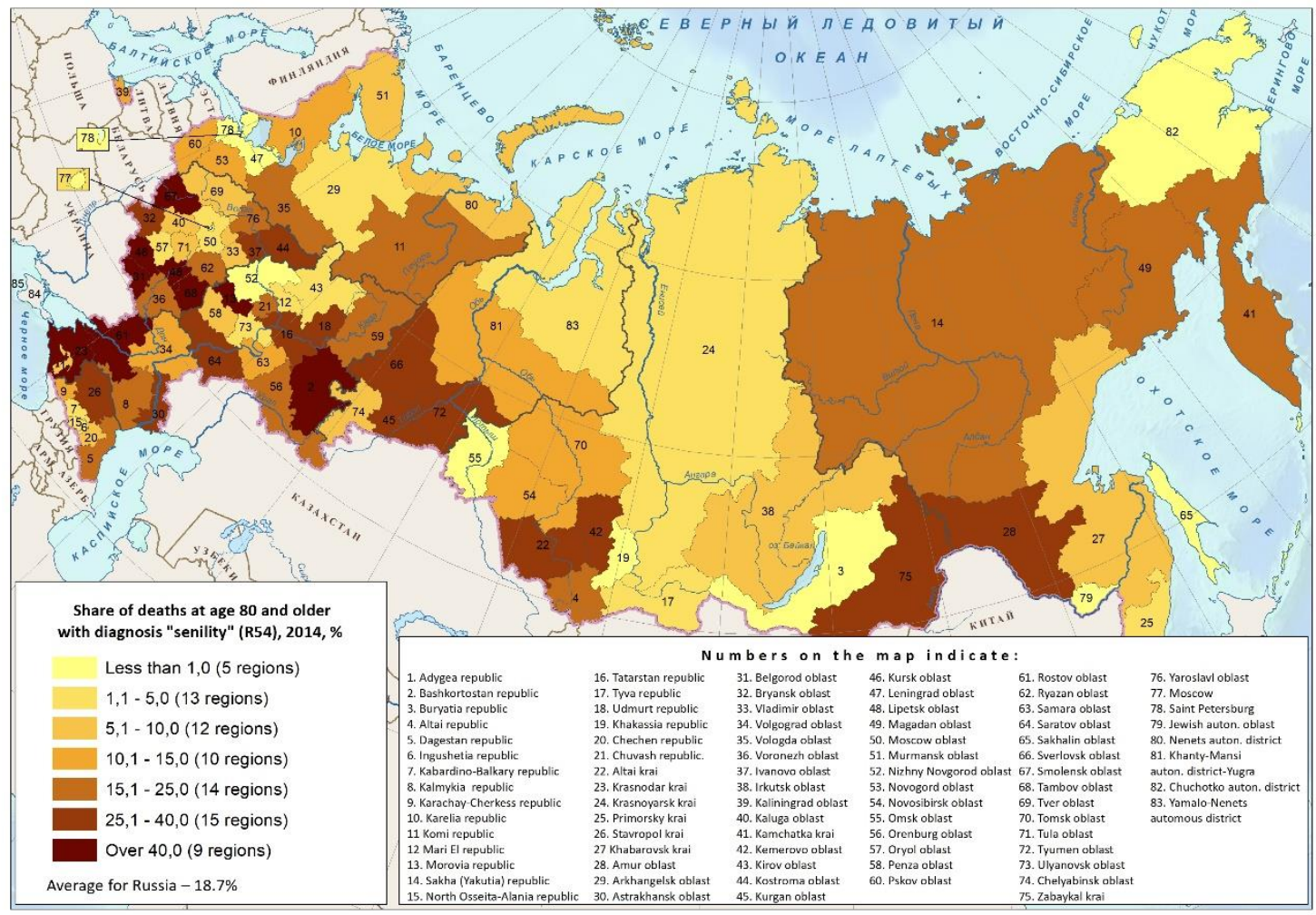

2014

Figure 18. Share of deaths at the age of 80 years and older with the diagnosis "senility", 2012 and 2014 
The change in the practice of coding the causes of death may, in principle, be valid, but it needs to be well founded. The issue requires special study, and the principles of coding should be unified, as the lack of uniformity seriously complicates analysis [Danilova 2015; Danilova et. al 2016]. In any case, the decrease in mortality from cardiovascular diseases in the regions as a result of changes in the practice of coding the causes of death should not be confused with real success in the fight against cardiovascular pathology.

\section{REFERENCES}

Biryukov V.A. (1979). Serdechno-sosudistyye zabolevaniya i prodolzhitel'nost' zhizni [Cardiovascular disease and life expectancy] // E.M. Andreev, A.G. Vishnevsky, eds. Prodolzhitel'nost' zhizni: analiz i modelirovaniye [Life expectancy: analysis and modeling]. Sbornik statey [Collection of articles]. M.: Statistika.

Danilova I., V.M. Shkolnikov, D.A. Jdanov, F. Meslé, J. Vallin (2016). Identifying potential differences in cause-of-death coding practices across Russian regions // Population Health Metrics. 14:8. URL: http://pophealthmetrics.biomedcentral.com/articles/10.1186/s12963016-0078-0 (accessed: 22.03.2016).

Danilova I.A. (2015). Problemy kachestva rossiyskoy statistiki prichin smerti v starcheskom vozraste [The issue of quality of Russian cause-specific mortality statistics at old ages] // Uspekhi gerontologii [Adv. Geront.]. 28(3): 409-414.

Grigoriev P., F. Meslé, V.M. Shkolnikov, E. Andreev, A. Fihel, M. Pechholdova, J. Vallin (2014). The Recent Mortality Decline in Russia: Beginning of the Cardiovascular Revolution? // Population and development review. 40(1): 107-129.

HLD (2015). Human Life-Table Database. the Max Planck Institute for Demographic Research (MPIDR) in Rostock, Germany, the Department of Demography at the University of California at Berkeley, USA and the Institut national d'études démographiques (INED) in Paris, France. URL: http://www.lifetable.de/ (accessed: 20.09.2015).

HMD (2015). The Human Mortality Database. Department of Demography at the University of California, Berkeley and Max Planck Institute for Demographic Research in Rostock, Germany. URL: http://mortality.org (accessed: 20.09.2015).

Kakorina Y.P. Starost' ne prichina [Senility is not a cause of death] (2013) // Meditsinskiy vestnik [Medical Annals]. № 8 (621). URL: http://www.medvestnik.ru/articles/starost_ne_prichina (accessed: 16.01.2016).

Leon D., V.M. Shkolnikov, M. McKee, N. Kiryanov, E. Andreev (2010). Alcohol increases circulatory disease mortality in Russia: acute and chronic effects or misattribution of cause? // International Journal of Epidemiology. 39:1279-1290

Meslé F., J. Vallin (2006). The health transition: Trends and prospects // G. Caselli, J. Vallin, G. Wunsch, eds. Demography: Analysis and synthesis. A Treatise in Population Studies: New York: Academic Press. Vol. II: 247-259.

Meslé F., J. Vallin (2011). Historical trends in mortality / R. G. Rogers, E. M. Crimmins, eds. International Handbook of Adult Mortality. Dordrecht: Springer: 9-47.

Meslé F., V.M. Shkolnikov, V. Hertrich, J. Vallin. (1996). Sovremennyye tendentsii smertnosti po prichinam smerti v Rossii: 1965-1994 [Modern trends in causes of death in Russia: 19651994]. Paris: INED. [Meslé F., V.M. Shkolnikov, V.Hertrich, J. Vallin. (1996). Tendances récentes de la mortalité par cause en Russie 1965-1994. Paris: INED]. 
RosBRiS (2015). Rossiyskaya baza dannykh po rozhdayemosti i smertnosti Tsentra demograficheskikh issledovaniy Rossiyskoy Ekonomicheskoy Shkoly [Russian Fertility and Mortality Database. Center for Demographic Research, Moscow (Russia)]. URL: http://www.demogr.nes.ru/index.php/ru/demogr_indicat/data (accessed: 20.09.2015).

Shkolnikov V.M., E.M. Andreev, M. McKee, D.A. Leon (2014). Rost prodolzhitel'nosti zhizni v Rossii 2000-kh godov [The increase in life expectancy in Russia of the 2000s] // Demograficheskoye obozreniye. 1(2): 5-37.

Terris M. (1976). The epidemiologic revolution, national health insurance and the role of health departments // American Journal of Public Health. 12 (66).

Vishnevsky A.G. (1986). Chelovecheskiy faktor v demograficheskom izmerenii [Human factor in the demographic dimension] // Kommunist [Communist]. 17: 69-80.

Vishnevsky A.G. (2014). Smertnost' v Rossii: nesostoyavshayasya vtoraya epidemiologicheskaya revolyutsiya [Mortality in Russia: the second epidemiologic revolution that never was] // Demograficheskoye obozreniye [Demographic Review]. №4: 540 .

Vishnevsky A.G., E.M. Andreev, S.A. Timonin (2015). Vliyaniye bolezney sistemy krovoobrashcheniya na demograficheskoye razvitiye Rossii [Impact of circulatory system diseases on the demographic development of Russia] // Analiticheskiy vestnik Soveta Federatsii Federal'nogo Sobraniya RF [Analytical Annals of the Federation Council of the Federal Assembly of the Russian Federation]: 61-78.

Vishnevsky A.G., V.M. Shkolnikov. (1997). Smertnost' v Rossii: glavnyye gruppy riska i prioritety deystviya [Mortality in Russia: main risk groups and priorities for acting]. M.: Nauchnyye doklady Moskovskogo Tsentra Karnegi [Scientific Reports of the Carnegie Moscow Center]. 19.

Vosproizvodstvo naseleniya SSSR [Population reproduction in the USSR] (1983) / A.G. Vishnevsky, A.G. Volkov, eds. M.: Statistika [Statistics].

WHO (1995). International statistical classification of diseases and related health problems. 10th Revision. Three volumes. Volume 1. Part 1.

WHO MD (2015). World health organization Mortality Database. WHO. URL: http://www.who.int/healthinfo/mortality_data/en/ (accessed: 20.09.2015).

Zaridze D., D. Maximovitch, A. Lazarev et al. (2009). Alcohol poisoning is a main determinant of recent mortality trends in Russia: evidence from a detailed analysis of mortality statistics and autopsies // International Journal of Epidemiology. 38: 143-53. 